\title{
„A cél, hogy legyen egy kisbabád, és minden mást félreteszel" - Etikai keretek az embri- ókkal kapcsolatos döntéseknél a lombikeljárás során
}

\author{
Vicsek Lilla - Bauer Zsófia - Szolnoki Noémi \\ https://doi.org/10.51624/SzocSzemle.2019.3.3 \\ Beérkezés: 2019. 03. 04. \\ Átdolgozott változat beérkezése: 2019. 07. १२. \\ Elfogadás: 2019. 10. 03.
}

\begin{abstract}
Összefoglaló: Amióta 1978-ban megszületett az első in vitro fertilizációs (IVF) kisbaba, világszerte rengeteg csecsemő fogant lombikbébi-eljárás segítségével. A tanulmány azt tárgyalja, hogy az eljárásban résztvevô páciensek beszámolóiban milyen etikai keretekkel találkozhatunk, és ezek miként jelennek meg az embrióval kapcsolatos döntéseik során. A cikk arra is kitér, hogy a meddőségi klinikán dolgozók mit kommunikálnak a páciensek felé, és ez miként befolyásolhatja gondolkodásukat. A kutatás keretében 20 félig strukturált interjú készült páciensekkel Magyarországon, valamint megfigyeléseket is végeztünk egy meddőségi klinikán. Manapság, amikor számos biopolitikai döntés a páciensekre hárul, lombikeljárásuk során is egy sor különféle, gyakran nehéz döntést kell meghozniuk. Az interjúkra támaszkodva a cikkben bemutatjuk, hogy a kérdezettek lombikeljárásról folytatott diskurzusában a domináns etikai keret a gyógykezelési etikai keret volt. Ennek a keretnek fontos jellemzője az embrióhierarchia: az interjúalanyok többsége különböző módokon konstruálta meg az embriókat az idő, a helyük és a biológiai jellemzőik függvényében, illetve elsősorban annak megfelelően, hogy azok miként tudtak hozzájárulni a kezelési céljukhoz. Az interjúalanyok beszámolói és a terepkutatás alapján kísérletet teszünk arra, hogy rekonstruáljuk, miként erősítheti tovább ezt az etikai keretet a klinikai környezet. A megerősítés többek között nyelvi kódok, vizuális tartalmak segítségével, valamint ontológiai manipuláció alkalmazása révén (amikor a biológiai entitásokat lényegileg más jellegúként prezentálják a pácienseknek aszerint, hogy milyen sorsot javasolnak számukra) valósult meg. A domináns etikai keret mellett tárgyaljuk a diskurzusokban jelentkező kisebbségi etikai kereteket is.
\end{abstract}

Kulcsszavak: reproduktív technológia, technológia és társadalom, lombikbébi-eljárás, etikai keretek

\section{Bevezetés}

Egyes országokban a születések 4-5 százaléka lombikeljárás (in vitro fertilizáció IVF) eredményeképp fogant baba. A technológia jelenléte Magyarországon sem elhanyagolható mértékű, bár még elmarad más - például a skandináv -országokétól. Egyes becslések szerint itthon az arány éves szinten 1,5-2\% (Szülészeti és Nőgyógy- 
ászati Szakmai Kollégium 2010), és várhatóan társadalmi és biológiai okoknál fogva a jövőben növekedni fog (Anderson 2005; Boivin et al. 2007).

$\mathrm{Az}$ asszisztált reproduktív technológiák ${ }^{1}$ terjedése több korábbi meghatározást és viszonyulást megkérdőjelez, többek között, hogy miként definiáljunk olyan fogalmakat, mint a test, a családok, a természet vagy az élet maga (Perrotta 2013). A reproduktív és egyéb biomedikális technológiák alkalmazása emellett számos etikai, morális és társadalmi kérdést is felvet (Sándor 2009). Egyes szerzők ezek fontosságát a 20. század más égető kérdéseihez hasonló nagyságrendűnek vélik (Thompson 2005).

Jelen tanulmány három diszciplína metszetében helyezkedik el. Ezek a szociológia, a Science and Technology Studies és a bioetika. A cikkben az embrióval ${ }^{2}$ kapcsolatos hozzáállásokat, az alkalmazott etikai kereteket vizsgáljuk. Elemzésünkben építünk a különböző tudományágak elméleti megfontolásaira és empirikus eredményeire. A szakirodalom ismertetése során láthatóvá válik, hogy az egyes tudományágakból milyen inspirációkat merítettünk.

A lombikeljárás során a pácienseknek számos, az embriót érintő döntést kell meghozniuk. Ezeket a döntési helyzeteket a következő részben részletesen is bemutatjuk. Jelen tanulmányunk célja, hogy a releváns elméleti és empirikus szakirodalomba beágyazva az embriókkal kapcsolatos etikai kereteket vizsgáljuk, amelyek alkalmazása részét képezi a laikus moralitásnak (Sayer 2004). A moralitás és az etika kifejezést ebben a tanulmányban azonos értelemben használjuk: mi tekinthető jó viselkedésnek, értékesnek. Az elemzés során az alábbi kutatási kérdésekre keressük a választ:

1. Milyen etikai kereteket használnak magyar lombikpáciensek az embriókkal kapcsolatos döntéseik meghozatala során?

2. Hogyan tekintenek a páciensek az embriókra ezekben az etikai keretekben?

Számos kutatás kimutatta, hogy az egészségügyi személyzet jelentős hatással lehet arra, hogy a páciensek miként gondolkodnak egy adott biológiai entitásról (Memmi 2012; Boltanski 2013- Mirlesse-Ville 2013, idézi Takács 2015). Ez alapján további kutatási kérdésként fogalmaztuk meg:

3. Mit kommunikálnak a klinikai dolgozók a klinika a páciensek felé az embriók és az etikai keretek kapcsán, és ez miként befolyásolhatja azt, ahogyan a páciensek végül gondolkodnak a kérdésről?

Míg a világ számos országában komoly nyilvános társadalmi vita alakult ki az embrió morális státuszáról (mi az embrió értéke, minek tekinthető az embrió) (Gaskell et al. 2006; Gottweis 2002; Kirejczyk 2008; Reis 2008), Magyarországon ez a nyilvá-

1 Az asszisztált reproduktív technológiák alatt olyan eljárásokat vagy kezeléseket értünk, amelyeknek célja a terhesség létrehozása, és ahol in vitro (laboratóriumi körülmények között) zajlik a petesejtek és a spermiumok vagy az embriók kezelése. Az egyik ilyen eljárás a lombikeljárás - azaz az in vitro fertilizáció (Zegers-Hochschild et al. 2009: 1521).

2 Az embrióknak több definíciója létezik, a kutatás során mi embriónak tekintettük a fejlődő organizmust a megtermékenyítéstől a megtermékenyítés után számított nyolcadik hét végéig (Dorland's Medical Dictionary for Health Consumers, 2007). 
nos eszmecsere elmaradt. A téma marginalizálódott egészen 2017 nyaráig, amikor Veres András püspök az embriókhoz és a mesterséges megtermékenyítéshez kapcsolódó etikai dilemmákról tett észrevételei több sajtóorgánumban is megjelentek (többek között a hvg.hu, magyarnarancs.hu, 888.hu, 444.hu, népszava.hu, index.hu is foglalkozott a témával). Kutatásunk adatfelvétele ugyanakkor korábban történt, tehát a válaszokban a 2017-es nyilvános vita hatásai még nem mutatkozhatnak meg.

Egyes országokban (például Olaszország) viták tárgya volt a mesterséges megtermékenyítés eljárása. Dilemmaként a létrehozott embriók számára fókuszáltak. Kérdésként fogalmazódott meg, hogy olyan eljárásokat alkalmazzanak, amelyek során keletkezhetnek olyan embriók, amelyek megmaradnak és nem kerülnek beültetésre, vagy csak és kizárólag annyi embrió létrehozása etikus, amennyi beültetésre is kerül női testbe. Utóbbi esetben a sikeresség aránya jóval alacsonyabb, emellett a költségek is magasabbak (Perrotta 2013). Más országokban, például az Egyesült Államokban és Nagy-Britanniában, a 21. század vitái sokkal inkább az embriók kutatási célra történő felhasználásával foglalkoztak, elsősorban az embrionális őssejtkutatásokhoz kapcsolódóan. A kérdésben a lombikeljárás azért érintett, mert az eljárások során megmaradt embriókat használhatják fel a kutatások során. A nyilvánosan zajló, közéleti viták gyakran szélsőségesen polarizáltak voltak, gyakorlatilag csak az elkötelezett kutatás párti és a kutatásellenes vélemények jelentek meg, az árnyaltabb állásfoglalásoknak nem maradt tér (Kitzinger 2007).

Magyarországon nincsen közvetlen kapcsolat az őssejtkutatás és a lombikeljárás között, hiszen a jogértelmezés alapján nem lehet magyar megmaradt embriókon vizsgálódni, az őssejttörzseket ezekhez a kutatásokhoz külföldről importálják. Csak a lombikeljárást és az abból származó embriók fagyasztását engedélyezi a törvény. A jogászokkal, orvosokkal és embriológusokkal készült szakértői interjúk alapján megállapítható, hogy mivel a megmaradt embriók nem használhatók fel embrionális őssejtkutatás során, és további kutatási lehetőségek szintén korlátozottak, így a párok gyakorlata vagy a lefagyasztás és tárolás, vagy pedig a megsemmisítés. A más pároknak történő adományozás rendkívül ritka.

A kormány 2013-ban az új alaptörvénybe belefoglalta az embriók védelmét, és egyes értelmezések szerint ez a lombikeljárás lehetőségeit is korlátozná. Ugyanakkor a mai napig ezek a korlátozások egyáltalán nem jelentek meg a gyakorlatban, sőt a kormány további támogatásokkal ösztönzi a meddő párok gyermekvállalását.

Reprezentatív kérdőíves kutatások eredményei alapján az is látható, hogy Magyarországon a mesterséges megtermékenyítés megítélése kifejezetten pozitív (Szalma 2014, 2016; Zavecz Research, 2017). Ehhez kapcsolódva számos empirikus vizsgálat azt is megerősíti, hogy a gyermekeknek nagy értéket tulajdonítanak a magyar társadalomban, és a magyarok fontosnak tartják, hogy legyen saját gyerekük (Miettinen-Szalma 2014; Szalma 2014). A gyermekvállalás ösztönzése kiemelt hangsúllyal szerepel a politikai térben is, számos - a gyermekek születését ösztönző - intézkedést vezettek be az utóbbi évek során. Sok más országhoz hasonlóan Ma- 
gyarországon is fontos a vérségi kapcsolat szülő és gyerek között. A szülő és gyerek közötti genetikai kapcsolatot megvalósító gyermekvállalást a magyarok pozitívabban ítélik meg, mint például az örökbefogadás révén létrejövőt (Neményi-Takács 2015).

A kutatás relevanciájának alapja, hogy még nem rendelkezünk tudással arról, miként tekintenek a magyarországi lombikpáciensek az embriókra, valamint, hogy milyen etikai keretekben gondolkodnak az embriókkal kapcsolatos döntéshozataluk során. A kutatás további hozadéka, hogy nemzetközi szinten is rendkívül keveset tudunk arról, hogyan ítélik meg és dolgozzák fel a lombikpáciensek a klinikai dolgozók embriókkal kapcsolatos kommunikációját, azaz milyen a klinikai kommunikáció az embriókról, és ez milyen hatással van a páciensekre és döntéseikre.

A tanulmányban először röviden bemutatjuk a lombikeljárás menetét és a folyamat során az embriókat érintő döntéseket, hogy világossá váljon az olvasók számára, milyen jellegű kérdésekkel szembesülnek, majd azt, milyen döntéseket kell meghozniuk a pácienseknek. A leírás során néhány releváns orvosi fogalom is ismertetésre kerül. Igyekeztünk a legfontosabb fogalmakra koncentrálni, azokra, amelyek ahhoz szükségesek, hogy érthető legyen az elemzés. A cikk döntéseket tárgyaló részét a szakirodalmi háttér felvázolása követi, amelybe a kutatást ágyaztuk. Egyfelől tárgyalunk etikai, szociológiai és Science and Technology Studies körébe eső írásokat, amelyek az embrióval és a hozzá kapcsolódó etikai kérdésekkel foglalkoznak. Másfelől a laikusok egészségügyi kérdésekhez kapcsolódó döntéseire és az ezekre gyakorolt orvosi befolyással foglalkozó szociológiai írásokra térünk ki. Ezután az adatok és módszerek, majd pedig az eredmények ismertetése következik.

\section{Az embriók útja a magyar klinikákon és a döntések}

A lombikeljárás a mesterséges megtermékenyítés egyik típusa, amelyik során a petesejt(ek) megtermékenyítése a méhen kívül (in vitro, azaz testen kívül), lombikban történik. Az IVF rendkívül pontos orvosi protokollnak megfelelően, meghatározott lépések szerint halad. A meddőség hátterében meghúzódó okok kivizsgálása után a lombikbébi-eljárás első lépése a hormonkezelés. Hormonok segítségével először leállítják a petefészek múködését, majd az ovulációt ellenőrizve szintén hormon felhasználásával túlstimulálják a petefészkeket (hormonstimuláció), hogy nagymennyiségű petesejt keletkezzen. A stimulációs szakasz sikeressége után kezdődhet a petesejtek leszívása. A petesejtek partnertől nyert hímivarsejtekkel történő megtermékenyítése után a létrejövő embriók fejlődését szigorúan figyelik, azok inkubátorban fejlődnek a beültetésig. Az embriók beültetése a méhbe tipikusan a harmadik vagy ötödik nap szokott lenni (Meniru 2004; Neumann 2011).

A világ különböző országaiban eltérő konfigurációkban működnek a lombikeljárások. Többek között eltérnek az országok abban, hogy milyen mértékú hormonstimulációt alkalmaznak, ennek eredményeképp hány embrió jön létre, át- 
lagosan hány embriót ültetnek be, milyen lehetőségek közül választhatnak a páciensek a maradék embriók kapcsán, milyen gyakran választják az egyes opciókat, valamint milyen módon történik a döntéshozatal ezekről. Egyes országokban vannak olyan konstrukciók is, amikor az összes létrehozott embriót be kell ültetni, ezért eleve kevés embriót hoznak létre.

Szakértői forrásaink ${ }^{3}$ szerint a magyarországi gyakorlatban hormonstimulációt szoktak alkalmazni, melynek célja sok petesejt stimulálása, és lehetőség szerint anynyi embrió létrehozása, hogy maradjanak embriók a beültetésen felül fagyasztásra is, amit egy következő lombikciklusban fel lehet használni. A páciensek számára a klinikai személyzet ad ajánlást a beültetett embriók számát illetően, amelyet a legtöbben el szoktak fogadni. Abban az időszakban, amikor interjúalanyaink lombikeljárásban vettek részt, az embriók közül tipikusan 2, ritkábban 3, és még ritkábban 1 került végül beültetésre. A beültethető embriók maximális számát törvény és szakmai protokoll is szabályozza (Szülészeti és Nőgyógyászati Szakmai Kollégium 2010). Eltérő, hogy egyes klinikákon mennyire szólhatnak bele a páciensnek abba, hogy hány embrió kerüljön beültetésre, de úgy tűnik, bizonyos határokon belül vannak esetek, amikor hatással lehetnek a beültetett embriók számára. Szakértői interjúalanyok beszámoltak olyan esetekről, amikor ők két embrió beültetését ajánlották, de a páciensek három embrió beültetését kérték, és erre meg is kapták a lehetőséget. Amennyiben több embrió kerül beültetésre, megnő a többes terhességek kialakulásának kockázata (ez hármas terhesség esetén magzatredukcióhoz is vezethet, amikor az egyik magzatot elpusztítják). Ami miatt a páciensek mégis kérni szokták, az, hogy úgy vélik, fontos, mert így növelni tudják esélyüket, mert idősebbek, vagy már a sokadik sikertelen lombikcikluson vannak túl. Beszámoltak a szakértői interjúalanyok olyan esetről is, ahol páciens amiatt kérte a hármas beültetést, mert ha két embriót ültettek volna be, akkor csak egy embriója marad. Ez problémát jelentett volna számára, hiszen egy embrió lefagyasztására azon a klinikán nem volt lehetôség, így megsemmisítették volna. Ennek elkerülésére kérte a páciens, hogy akkor ültessék azt is be.

A klinikákon a legjobb embrióminősítést elért embriókat ültetik be. Az embrióminősítés egy valószínűségeken alapuló osztályozás. Az embriókat az embriológusok több szempont alapján osztályozzák. A kedvezőtlen osztályozást elért embriók egy részénél tulajdonképpen csak annyi állítható, hogy csekély valószínűséggel vezetnének majd sikeres terhességhez, de ez a valószínüség nem nulla. Sőt rossz minősítésű, „csúnya” embriók esetében is számoltak már be sikeres terhességekről (Ehrich-Williams-Farsides 2010). Ráadásul a lombikeljárás során alkalmazott hagyományos embrióminősítés nem a genetikai rendellenességeket vizsgálja. Amenynyiben embrióminősítés során egy embrió rossz osztályozást kap, az nem jelenti azt,

3 A magyarországi helyzet bemutatását a cikknek ebben a részében 12 szakértői interjúra építjük elsősorban (meddőségi klinikákon folytatott egészségügyi dolgozókkal interjúk, interjúk jogászokkal). Valamint, ahol utalunk rá, felhasználjuk terepkutatásunk egyes eredményeit is, erről bővebben az Adatok és módszerek részben írunk majd. Ugyanitt bővebben még írunk azokról a módszerekről, amelyeket az elemzés fö részéhez használtunk fel. 
hogy szükségképpen genetikai rendellenessége lenne, ugyanakkor jó minősítésű embrió hordozhat genetikai rendellenességet (Munné et al 2007).

Amennyiben marad embrió a beültetésre kerülőkön felül, amelyik elér egy meghatározott minősítést, azokról a pácienseknek egy nyomtatványon nyilatkozniuk kell, hogy milyen célra szánják őket. A szabályozás következtében a lehetséges opciók: fagyasztás, egyes esetekben felajánlás kutatóintézetnek (de nem őssejtkutatási célra, hanem például reprodukciós technológiák fejlesztését szolgáló kutatások számára - ugyanakkor ez nem mindig lehetőség), felajánlás más pároknak, valamint megsemmisítés. Sok klinikán a fagyasztás a leggyakrabban választott opció, ha van megfelelő jó minősítésű embrió, ezt ajánlják a pácienseknek (ahol kevésbé fejlett technológiát használnak és rosszabb a sikerráta a fagyasztásoknál, egyes esetekben az is feltétel, hogy minimum kettő fagyasztásra alkalmas embrió álljon rendelkezésre).

A fagyasztás az embrióminősítés alapján bizonyos szintet elért embriók esetében merül fel, és ekkor prezentálják lehetőségként a pácienseknek. Rossz minősítésű embriók fagyasztását mint opciót alapvetően nem kínálják fel - de egyik klinikán beszámoltak arról, hogy volt már olyan eset, amikor a páciens kérte, és külön nyilatkozatot kitöltve elérhetővé vált számára a fagyasztás lehetősége. Laboratóriumi megfigyelés során szintén megerősítést nyert, hogy voltak egyes speciális esetek, amikor nem kedvező minősítésű embriókat mégis lefagyasztottak (pl. amikor minősítésben közel állt a kedvező kategóriához, és amúgy is fagyasztottak mellé másik embriót, vagy amikor a férfinak mútét kellett volna, hogy további hímivarsejtekhez jussanak, stb.).

A fagyasztás eredménye, hogy a felhasználatlan embriók nem kerülnek az egyes lombikciklusokban megsemmisítésre. Az opció lehetővé teszi, hogy egy újabb lombikciklus során ne kelljen hormonstimulációt és petesejtleszívást végezni, hanem a fagyasztott embriókkal lehessen az eljárást elvégezni, így hamarabb és költséghatékonyabban kerülhet sor újabb ciklusra. A fagyasztott embriók sorsáról a páciensek dönthetnek. Ha szeretnének gyereket, felhasználják saját újabb IVF-ciklusukhoz. Ha valamilyen ok miatt nem használják fel erre a célra (akár mert közben sikeresen megvalósult egy vagy több terhességük), dönthetnek úgy is, hogy más párnak adományozzák. Opció a felhasználás mellett egyes esetekben a kutatóintézetnek történő felajánlás; díj fizetése mellett a tárolás meghosszabbítása (a törvényileg lehetséges időkereteken belül); illetve felhasználás nélkül felengedtetik. Jelenleg az tapasztalható, hogy a lombikeljárások „mellékterméke” a felhasználásra nem kerülő maradék fagyasztott embriók tömege. Magyarországon jelenleg sok ezer olyan embrió van, amit várhatóan már nem fog senki sem felhasználni.

Bár a tipikus útnak az tekinthető, hogy a lombikeljárások során sok embrió létrehozását célozzák meg, vannak olyan esetek, amikor páciensi kérésre nem ez történik. A szakértői interjúalanyok beszámoltak többek között az egyik klinikán történt friss esetről, amikor vallási okból kérte egy pár, hogy csak annyi embriót hozzanak létre, ameny- 
nyit be is fognak ültetni, és minősítéstől függetlenül ültessék be az összes létrehozott embriót.

Az embriók kezeléséhez kapcsolódóan felfedezhetők különbségek az egyes magyarországi klinikák gyakorlatában. A klinikák eltérhetnek egymástól a fagyasztások arányában és módjában (pl. párosával vagy egyesével fagyasztják az embriókat). Ahol csak párosával fagyasztanak, ott, ha egy embrió marad, az megsemmisítésre kerülhet, vagy ritkán olyan is előfordulhat, hogy eggyel többet ültetnek be a ciklus során. Emellett különbség lehet, hogy valóban múködik-e az embriók kutatási célú felajánlása és felhasználása, mint lehetőség. Ezeknek megfelelően a páciensekre háruló számos döntés egyike (amely érinti az embriók sorsát is), hogy melyik meddőségi klinikához forduljanak. A kutatásunk idején 16 intézményben foglalkoztak Magyarországon mesterséges megtermékenyítéses eljárásokkal.

Potenciálisan tehát többek között a következő, az embriókat érintő döntései lehetnek a pácienseknek az eljárás során:

- Lombikeljárásban részvétel

- Klinikák közötti választás (különböző gyakorlatuk van embriókkal)

- Hormonstimuláció és annak mértéke (befolyásolja a létrejövő embriók számát)

- Hány embrió kerüljön létrehozásra (pl. csak annyi, amennyi beültetésre kerül majd, vagy több)

- Hány embrió kerüljön beültetésre

- Fagyasztás választása vagy elutasítása maradék jó minősítésű embriók esetén

- Fagyasztás választása vagy elutasítása maradék rossz minősítésű embriók esetén

- Adományozás választása vagy elutasítása - kutatás céljára vagy más pároknak

- Új ciklus friss vagy fagyasztott embriókkal történjen

- Fagyasztott embriók tárolásának meghosszabbítása vagy megszüntetése

- Klinika váltásnál meglévő fagyasztott embriók továbbvitele vagy otthagyása

Sok döntést alapvetően meghatároznak a törvényi, szabályozási és orvostudományi korlátok, így azokban kisebb a páciensek mozgástere (pl. bizonyos embriószámon felül nem ültetnek be embriót). Vannak olyan opciók, amelyeket alapból sztenderdizáltan, meghatározott módokon kerülnek bemutatásra a klinikán, hangsúlyozva, hogy mi az elterjedt, ajánlott út (pl. egy adott embrióminősítési szintet elérő embriók lefagyasztása). Előfordulnak azonban olyan utak is, amelyekről nem is szükségképpen tudnak a páciensek, hogy lenne lehetőségük beleszólni, hacsak nem kiemelten informáltak. Ugyanakkor olyan döntéseket is meg kell hozniuk, amelyekbe a klinika csak minimálisan szól bele. Ilyen többek között, hogy mi történjen a fagyasztott embriókkal, ha a pár úgy érzi, éppen nincsen rájuk szüksége, mert létre- 
jött terhesség: meghosszabbítsák a tárolást, megszüntessék, vagy eladományozzák az embriót.

\section{Szakirodalmi háttér}

Etikai keretek és az embriók morális státusza

Az etikai irodalomban régóta folynak viták az embrió morális státuszáról. Warren (1997: 3) meghatározásában az entitás morális státusza azt jelenti, hogy „morális szempontból figyelembe veendő”, „olyan entitás, amely iránt a morális szereplőknek morális kötelességei vannak vagy lehetnek. Ha egy entitásnak morális státusza van, akkor nem kezelhetjük bármely módon, ahogy csak szeretnénk”. Több típusú morális státusz létezik, és a bioetikusok között sincs egyetértés abban, hogy az embrió ezek közül melyikkel rendelkezik. Egyes szerzők (Warren 1997) inkább dolgokhoz, nem emberi élőlényekhez hasonló morális státusszal ruházzák fel, míg mások (Shannon-Wolter 1990) - például katolikus teológiai megközelítésből - szinte hasonló státuszúnak tekintik, mint a felnőtt embert. Egyes álláspontok szerint az embriók mindössze sejtek halmazának tekinthetők, megint mások emberi lényként fogják fel őket (Meyer-Nelson 2001; Warnock 1985). Ezekben az álláspontokban közös, hogy sokszor „az” embrió morális státuszáról beszélnek, mintha az embrió csupán egyfajta entitás lehetne. Léteznek ugyanakkor olyan megközelítések is a bioetikai irodalomban, amelyek megkülönböztetéseket tesznek például az embrió kora, illetve helye szempontjából. Vannak olyan álláspontok is, amelyek 14 napos korától tekinti az embriót emberi életnek (Nakano-Okuno 2006), de létezik olyan megközelítés is, ami attól teszi függővé a morális státuszt, hogy van-e funkcionális kapcsolat az anyaméh ás az embrió között (Agar 2007).

A szociológia és a Science and Technology Studies (STS) körébe tartozó irodalmak azt hangsúlyozzák, hogy az embriók nemcsak materiális, hanem egyben társadalmi-kulturális entitások is, tehát társadalmi és kulturális tényezők is befolyásolják azt, ahogy gondolkodunk róluk (Franklin 2013). Az embrió sokszor nem egyfajta entitásként jelenik meg ezekben az írásokban, hanem figyelembe veszik, hogy a valóságban az embriók különböző konkrét helyzetekben fordulnak elő. Ezek a különbözőségek pedig kihathatnak arra, ahogy a társadalmi szereplők megítélik őket, és milyen morális, ontológiai és társadalmi státuszt tulajdonítanak nekik (Franklin 2013; Perrotta 2013).

A bemutatott embrióknak tulajdonított különböző jelentések részei az IVF technopolitikai kultúrájának (Felt-Fochler-Winkler 2010). Latour és Akrich (1991; 1992) - építve Felt és kollégái technopolitikai kultúrafogalmára - a politikai és a technológiai konfigurációk együttes fejlődését hangsúlyozzák, valamint azt, hogy lehetnek kulturális különbségek a társadalmak között abban, ahogyan a fejlődés történik. Különböző biomedikális technológiák megítélését vizsgálva (mint például a genetikai tesztelés) arra a következtetésre jutottak, hogy a globális trendek és 
az európai harmonizációs törekvések ellenére nagy különbségek lehetnek az egyes országok technopolitikai kultúrájában. Sok tekintetben eltérő lehet, ahogy a technológia jelen van az egyes társadalmakban, valamint abban is jelentős különbség mutatkozhat, ahogy a társadalom tagjai viszonyulnak ezekhez a technológiákhoz. Haimes és munkatársai 2008-as kutatásukban szintén azt hangsúlyozzák, hogy a társadalmi kontextus függvényében nagy különbségek lehetnek abban, ahogy az embriókra tekintenek az emberek.

A legújabb kutatások jelentős része az embriókat érintő számtalan páciensdöntés egy-egy aspektusával foglalkozik, például a 21. században fókuszba került az adományozás kérdése (De Lacey 2007; Firth et al. 2011; Jin et al 2013; Roberts 2007; Waldby-Caroll 2012). A kutatások közül számos olyan országban készült, ahol intenzív közéleti és társadalmi vita zajlott az embriók morális státuszáról.

Roberts (2007) a beültetés után megmaradó életképes embriók fagyasztására vonatkozó döntéseket vizsgálta. Ecuadori terepmunkája során azt találta, hogy azt a lehetőséget, miszerint a beültetésre nem kerülő életképes embriók fagyasztásra kerülhetnek, különféle etikai keretekben értelmezték, ami befolyásolhatta döntéseiket. Egyes klinikai dolgozók és páciensek életetikai keretben gondolkodtak, míg mások rokonságetikai keretben. Roberts (2007) rokonságetikai keretnek tekintette azt a szemléletet, amely az embriókat a rokonsági viszonyok részeként értelmezi. Az ebben a keretben gondolkodók attól féltek, hogy visszaélés történhet a fagyasztott embriókkal. Aggódtak, hogy az embriók esetleg kiesnek a rokonsági hálóból, ha idegenekhez kerülnek. Ezzel szemben az absztrakt életetikai érvelésben egy általánosan érvényes absztrakt elv miatt foglalkoznak az embrió státuszával, és nem amiatt, mert potenciális rokonnak, a család részeként tekintenek rá. Ez a percepció értékesnek tekint minden embriót, függetlenül attól, hogy kapcsolódik-e a családhoz. Az életetikai keretet alkalmazók pozitívan ítélték meg a fagyasztás lehetőségét, és éltek is vele, míg a rokonságetikai keretben gondolkodók negatívan, ezért bizonyos klinikákon alacsony volt a fagyasztási arány.

Jin és munkatársai (2013) olyan kínai pácienseket tanulmányoztak, akik nem terveztek további eljárásokban részt venni. Ők már befejezték sikeres lombikkezelésüket, azaz volt gyerekük, de a megszületett babájuk mellett rendelkeztek fagyasztott embriókkal is. Megállapításaik szerint több etikai és egyéb faktor befolyásolta döntéseiket. Amikor az embriók további sorsáról kellett rendelkezniük, a morális státusza meghatározó tényező volt azok számára, akik a további fagyasztás mellett döntöttek. Akik a felengedés, azaz a fagyasztás megszüntetése mellett döntöttek, a tárolási költségeket jelölték fontos érvként.

Annak ellenére, hogy zömében különböző speciális páciensi alpopulációk körében vizsgálták az embriókép kérdését (pl. olyanoknál, akik donor petesejttel szültek, vagy olyanok esetében, akik sikeres lombikeljárásuk után terhességük alatt kutatási célú donációra lettek felkérve, stb.), a különböző kutatásokban mégis felfedezhetők hasonlóságok. Ezek a külföldi kutatások azt mutatták, hogy más lehet az embriók megíté- 
lése helyzetüktől függően (Haimes et al. 2008) - például másként ítélhetnek meg egy anyaméhben lévő embriót, mint egy fagyasztott embriót (Provoost et al. 2011). Emellett eltérések lehetnek abban is, ahogy különböző európai országokban tekintenek az embriókra a páciensek. Haimes és szerzőtársai (2008) például azt találták, hogy angol és svájci interjúalanyaik teljesen máshogy vélekedtek az embrióról: az angolok inkább tekintették már őket babáknak, míg ez a svájciakra kevésbé volt jellemző.

$\mathrm{Az}$ asszisztált reproduktív technológiákhoz kapcsolódóan a kutatások az egészségügyi személyzet esetében is elsősorban egy-egy döntésre fókuszálva vizsgálták az etika kérdéskörét. Számos cikk foglalkozott az utóbbi időben egyfelől a preimplantációs genetikai diagnózis etikai kérdéseivel, amely egy olyan eljárás, ami az embriókat genetikailag is szűri és lombikeljárás során, másfelől az embriók kutatási célú adományozásának megítélésével (Baruch et al 2008; Ehrich et al. 2011, 2012; Kalfoglou et al. 2005; Meister et al. 2005; Wennberg et al. 2016).

Svendsen és Koch (2008) klinikai dolgozók és kutatók körében végzett dániai kutatásuk során azt vizsgálták, hogyan használják fel őssejtkutatáshoz a lombikeljárás során feleslegesnek ítélt embriókat. Munkájuk során azt találták, hogy az embriók kapcsán elsősorban a gyógykezelés-etikai keret volt a jellemző. Nem fejtik ki részletesen ezt az etikai keretet, mert nem ez volt tanulmányuk fókusza, pusztán annyit jegyeznek meg róla, hogy ezt a keretet az jellemzi, hogy a páciensek saját érdekeit az embriók érdekei elé helyezi. Fontos megállapításuk volt, hogy a maradék embriók nem pusztán biológiai tények: az, hogy egy általuk megvizsgált klinikán mely embriók minősültek maradéknak és a szomszéd kutatási klinika céljaira felhasználhatónak, komplex döntési folyamatok eredménye volt, és nem pusztán az embrió biológiai adottságainak kérdése.

Jelen tanulmánynak más áll a vizsgálati fókuszában, mint a legtöbb külföldi kutatásnak: egy jól körülhatárolható döntés helyett a döntéshozatal szélesebb spektrumát vizsgáltuk. Az eltérő kutatási kérdés mellett a vizsgálat egy a korábbi vizsgálatok kontextusától sokban különböző országban készült. Ismereteink szerint nincs más szociológiai kutatás, amely a lombikeljárás során meghozott döntések etikáját, valamint az embriókhoz kapcsolódó etikai kereteket vizsgálta volna Magyarországon.

\section{A laikusok döntései és az ezekre gyakorolt orvosi befolyás}

Dominique Memmi (2003; 2012) megállapítja, hogy az utóbbi évtizedekben jelentős változások figyelhetők meg az élet kezdetére és végére vonatkozó egyéni döntések irányításában és azok meghozatalában. A korábbi állami tiltó és büntető hozzáállás helyét elsősorban a felügyeleti funkció vette át. Az orvosi mező szereplőire ruházzák, azaz továbbdelegálják a korábban állami szférában megvalósított diszkurzív felügyeletet. A felelősséggel és jogkörökkel felruházott aktorok esetünkben az orvosok, ápolónők, szülésznők, pszichológusok és családtanácsadók. A döntési jogkörök, a kontroll másik részét viszont közvetlenül a páciensekre ruházzák át: az állam átengedi számukra egyes kérdések „racionális menedzselését”. Memmi a kontroll és 
döntések delegálását az életre vonatkozó kérdésekben delegált biopolitikának nevezi. Elvárás a delegált biopolitika ideáljában, hogy a páciensek racionálisan, azaz indulataikat és érzelmeiket kordában tartva döntsenek a saját testükkel kapcsolatos és az életre és halálra vonatkozó kérdésekben. Felmerül a kétely azonban azzal kapcsolatban, hogy valójában mennyire tudnak felkészülni és alkalmazkodni ehhez az elváráshoz a páciensek. Memmi (2012) azt találta, hogy az alkalmazkodóképesség mértéke társadalmi csoportonként eltérő lehet.

Számos szerző hangsúlyozza, hogy a páciensek döntéseire sok esetben nagy hatással lehetnek az egészségügyi személyzettől kapott információk (Memmi 2012; Fannin 2012). A velük folytatott konzultációk biztosítják azt a teret, amelyben az élet kezdetére vonatkozóan meghatározó információk, vélemények és tanácsok születnek. Ők mondják el a konzultációk során, hogy mit kell látniuk a pácienseknek egy ultrahangfelvételen, illetve, hogy milyen jelentőséggel kell a látottakat felruházniuk. Több kutatás (Memmi 2012; Boltanski 2013- Mirlesse-Ville 2013, idézi Takács 2015) is vizsgálta ezeket a konzultációkat, bár nem konkrétan az asszisztált reprodukció kapcsán, de a fogamzáshoz kapcsolódó témakörben. Prenatális ultrahang-konzultációkat elemeztek, és azt találták, hogy az orvosok más kifejezéseket használtak a magzatok jellemzésére, amikor olyan ultrahangképeket elemeztek, ahol a magzatnak olyan betegsége volt, ami miatt szerintük nem kellett volna elvetetni a magzatot (pl. nyúlszáj), és más kifejezéseket olyan esetekben, amikor pedig olyan betegségekkel, amikről az orvosok úgy ítélték meg, hogy abortusz lenne célszerű (pl. egyes szívbetegségek). Az ultrahangfelvételek esetében olyan technológiai vívmányról van szó, ahol az orvosok és a páciensek ismeretei közötti különbségek miatt az utóbbiak különösen függő helyzetbe kerültek. Bár a felvételeket a páciensek is láthatják, maguktól azonban nem tudják értelmezni azokat. Az orvosok mondják meg, mit kell látniuk a felvételeken. A páciensek befolyásolása a szem pozitivizmusának „nevezett sajátos szakmai illúzión is alapszik, ahol a látottak szolgálnak bizonyítékul" (Memmi 2012: 86-87). Az ultrahangfelvétel szolgáltatja a bizonyítékot ahhoz, amit az orvosok mondanak - ezekkel támasztják alá szakmai véleményüket.

Boltanski (2012) ontológiai manipulációnak nevezi azt a jelenséget, amikor a magzatokat az egészségügyi személyzet lényegileg különböző jellegű entitásként prezentálja a páciensek felé annak megfelelően, hogy milyen sorsot javasolnak számukra. Olyan esetben, ahol a magzatok megtartásra kerülnek, a magzatok perszonalizációja jellemző, gyakran, amikor az ultrahangkép alapján beszéltek róla, a magzatot megszemélyesítő kifejezéseket használnak („milyen kis félénk”, „most nem akarja megmutatni”, „integet nekünk”, „milyen kedves, hogy felénk fordul”). Amennyiben viszont abortuszt javasolt az orvos, akkor az orvosi diskurzusban a magzat dehumanizációjára került sor, és nem lett emberi jellemzőkkel felruházva a magzat. Ezek a technikák elősegíthetik, hogy a páciensek az orvos által javasoltaknak megfelelően döntsenek (Boltanski 2012; Memmi 2012; Fannin 2012; Takács 2012, 2015a, 2015b). 
A szakértelemhez kapcsolódó hatalmi dimenzión túl más szempontból is aszimmetrikus az orvos-páciens viszony: az orvos a segítő, míg a páciens a segítségkérő szerepében van. Az orvos számára egy rutinhelyzetről van szó, míg a páciens részéről érintettség és félelem jelentkezhet, valamint döntési jogköreikben is eltérések lehetnek (Málovics és mtsai 2006).

Az orvosi befolyás mértékét csökkentheti, hogy az orvosok sokszor túlterheltek lehetnek, és ennek következtében esetleg nincs idejük részletekbe menően megvalósítani a diszkurzív felügyeletet (Memmi 2012). A páciensek az orvosokon kívül másokkal is konzultálhatnak, akár az interneten is kereshetnek információkat, kérhetnek tanácsot fórumokon (Bauer 2013, 2017), egyfajta „laikus szakértőkké” válhatnak. Az orvos iránti bizalom mértéke is hathat ezekben a helyzetekben. Jelen cikk egyik szerzője azt találta hazai meddőségi fórumok elemzésekor, hogy a fórumozó páciensek egy része körében bizalmatlanság jelentkezett az asszisztált reproduktív eljárásokat végző orvosokkal szemben (Bauer 2014a).

Memmi (2003) is elsősorban a francia helyzet elemzéséből indul ki, amikor a delegált biopolitika szerepének előtérbe kerülését hangsúlyozza, de könnyen belátható, hogy sok más társadalomra - így Magyarországra - alkalmazható számos megállapítása. A hosszabb ívú változásokkal kapcsolatban hazánkra is jellemző, hogy az állam az egészségügyi személyzet és a páciensek körébe delegál egyes döntéseket, amelyek korábban az állam hatókörébe tartoztak. Ugyanakkor eltérések vannak az egyes társadalmak között abban, hogy milyen mértékben delegálódnak jogkörök az egyes szereplőkre, és milyen a viszony az egyes szereplők között: milyen pl. a kapcsolat orvos és páciens között, milyen mértékben befolyásolják az orvosok azt, ami a kezelések során történik, mennyire tradicionális-paternalisztikus a viszony, és milyen mértékben van döntési autonómiájuk a pácienseknek (Bauer2014b). Magyarországon egyes kvalitatív kutatások szerint paternalista stílus uralkodik az orvosok körében (Málovics et al. 2009), ugyanakkor az is látszik, hogy a páciensek egy részénél már jelentkezik az igény egy másikfajta viszonyra (Bauer 2017).

A lombikeljárás során megfigyelt döntési helyzeteket is elemezhetjük a delegált biopolitika fogalmi kereteivel. Egyes kérdésekben az egészségügyi személyzet gyakorol diszkurzív felügyeletet, valamint a döntések egy részét az egészségügyi személyzet hozza meg, míg egy másik részük a páciensekre hárul. Számos olyan döntést kell meghozniuk a pácienseknek, amelyek az embriók sorsát érintik, de születnek olyanok is, amelyekbe a páciensek csak beleszólhatnak.

\section{Adatok és módszer}

A feltáró kutatás során húsz lombikeljárásban részt vevő nővel készült félig strukturált interjú. Kizáró kritérium volt, ha még nem került sor a beültetésre, vagy ha három évnél régebben volt az utolsó IVF-ciklus. Az interjúk közül kettőre Budapesten, a többire más magyarországi településeken került sor: köztük kisvárosban és 
falvakban is. ${ }^{4} \mathrm{Az}$ interjúalanyok közül a legfiatalabb 30 éves volt, a legidősebb pedig 43. Néhány kivétellel mindegyikük már egynél több beültetésen esett át. Az interjúalanyok közül 12-nek nem volt az interjú időpontjában még gyereke, de ketten közülük már a terhesség későbbi fázisaiban jártak. Akiknek volt már gyerekük, közülük többüket lombikeljárás segítette. Egy kivétellel az interjú időpontjában is párkapcsolatban éltek az interjúalanyok, és ez szinte kivétel nélkül házasságot jelentett. Az interjúalanyok közül 17-en felsőfokú végzettséggel rendelkeztek. 13 interjúalany vallásosnak vallotta magát - és többen kifejezetten említették, hogy katolikusok. Az interjúalanyok felének budapesti klinikákon volt csak lombikeljárási tapasztalata, a többieknek csak vidéken vagy vidéken és Budapesten egyaránt. Összesen a magyarországi meddőségi klinikák nagyjából feléről származtak tőlük információink. Az interjúalanyokat két külön úton toboroztuk. Egy részük tematikus internetes fórumokon és csoportokban közzétett felhívásra jelentkezett, többen pedig hólabda módszerrel kerültek a mintánkba.

Az elemzés nőkre koncentrál. Ezt nagyrészt a gyakorlati szervezhetőség indokolta: sokkal könnyebb volt női interjúalanyokat találni. Egy olyan vegyes mintának pedig nem láttuk volna értelmét, ami nagyon nagy arányban nőkből állt volna, de nem teljesen. Az internetes fórumokon lényegében kizárólag nők (vagy magukat nőknek való) írnak, és tágítva a mintát a hólabda módszer révén is elsősorban nőkhöz jutottunk el. (Ezeknek a nőknek egyes esetekben a párjai vállalták volna az interjút, míg más esetekben elzárkóztak a lehetőségtől. De nehézkesen ment, hogy megkérjék a párjukat erre. Ott, ahol férfi meddőségi probléma miatt fordultak lombikeljáráshoz, a női interjúalanyok több esetben is említették, hogy a férfi szégyent érez az eljárás kapcsán). Más reprodukcióval kapcsolatos kutatások során az derült ki, hogy egyes reprodukciót érintő részkérdésekben a nők tájékozottabbak, és a döntések egy része rájuk hárul (Reed 2012). Jelen kutatás során is az látszott, hogy előfordultak olyan, az interjúalanyok által kisebb jelentőségűnek tartott döntések, amelyeket önállóan hoztak meg, férfi párjuk bevonása nélkül.

Az interjúk hossza tipikusan egy óra és két óra között volt. Mivel érzékeny témát vizsgáltunk egy sérülékeny populáció esetében, ezért különös gondot fordítottunk arra a kérdezés során, hogy érzelmileg igyekezzünk ráhangolódni az interjúalanyokra. A kölcsönös bizalom és intim hangulat megteremtése végett olyan kérdéseket is feltettünk, amelyek nemcsak az embriókkal foglalkoztak. Az interjúvázlatban kérdeztünk a lombikeljárás folyamatáról, arról, hogy milyen szempontokat vettek figyelembe egyes döntéseik meghozatalakor és hogyan élték meg a folyamatot, mi foglalkoztatta őket, mi okozott számukra érzelmi nehézséget és mit éltek meg pozitívumként. A továbbiakban rákérdeztünk, miket tudtak az egyes embriókkal kapcsolatban, milyen információkat kaptak, és miket tartalmazott az orvosokkal, egészségügyi személyzettel kapcsolatos kommunikációjuk az embriók kapcsán. Úgy

4 Az interjúkat a három szerző, valamint Paksi Veronika készítette. 
vettük észre, hogy - még ha sokszor nehéz érzelmi helyzetekrôl számoltak is be sokaknak mintha lelkileg jót tett volna, hogy szabadon, megértő hallgatóságnak beszélhettek tapasztalataikról és érzelmeikről.

Annak vizsgálatára, hogy a klinika mit és hogyan kommunikál a páciensek felé és mindez hogyan befolyásolja őket, jó módszer lehetne a megfigyelés, melynek része olyan klinikai interakciók vizsgálata, ahol egészségügyi személyzet kommunikál pácienssel. Külföldi kutatások a prenatális diagnózisok kapcsán, amelyeket bemutattunk a szakirodalmi részben, sokszor ezt a fajta megfigyelést alkalmazták. A kutatás során a vizsgált klinikán egyrészt laboratóriumi munkát figyeltük meg és az embriológusok és asszisztensek egymással való interakcióit. Másrészt tanulmányoztuk a klinikai honlapot, a klinika által a páciensek adott írásos tájékoztatókat, nyomtatványokat, űrlapokat. Ezenfelül több száz beazonosítás nélküli embrióminősítési lapot vizsgáltunk, és interjúkat készítettünk az egészségügyi személyzettel (orvosokkal, nővérekkel, embriológusokkal, asszisztensekkel). Az interjúk vezérfonala a terepmunka során formálódott. Vezérfonal nélküli, spontán kérdezések is előfordultak a helyszínen a megfigyeltek alapján. A kutatás során nem akartuk a páciens-klinikai dolgozókra vonatkozó interakciók megfigyelését végezni, mert úgy véltük, sokszor épp elég nehéz helyzet a páciensek számára a lombikeljárás, nem akartuk plusz érzelmi teherként rájuk helyezni, hogy ott a klinikán még arról is dönteniük kelljen, engedélyezik-e a saját megfigyelésüket vagy sem. Tudunk olyan külföldi kutatásról, ahol a szociológus kutatók köpenyt öltöttek, és nem közölték a páciensekkel, hogy megfigyelik őket, hanem úgy tettek, mintha a klinikai személyzet része lennének. Ez a megoldás etikai okokból sem volt szimpatikus számunkra. Így viszont a páciensek és a személyzet utólagos interpretációjában ismerhetjük csak meg, mit mondott nekik az interakciók során az egészségügyi személyzet, ami sokkal korlátozottabb, szűrtebb információ. További korlátját jelenti a kutatásnak az is, hogy a terepkutatást csak egyetlen klinikán végeztük, és interjúalanyainknak csak egy része volt ezen a klinikán páciens. Az eredmények részben elsősorban az interjúk eredményeire támaszkodunk. A terepkutatás így elsősorban inkább háttérinformációkat adott, ugyanakkor egy-két fontos adalékot is szolgáltatott az egészségügyi személyzet ontológiai manipulációjára vonatkozóan, emiatt tartjuk fontosnak belevenni az elemzésbe (ontológiai manipulációnak Boltanski (2013) nyomán azt tekintjük, amikor a biológiai entitásokat lényegileg más jellegúnek prezentálják a pácienseknek aszerint, hogy milyen sorsot javasolnak számukra).

Az interjúzásra és a terepkutatásra 2014 áprilisa és 2015 novembere között került sor.

$\mathrm{Az}$ eredmények értékelésénél figyelembe kell venni a szelekciós hatást is, hogy várhatóan miben különbözhetnek azok, akik vállalkoznak egy ilyen interjúra, azoktól, akik elutasítanak egy ilyen beszélgetést. Vélhetően inkább olyanok vállalták a kutatásban a részvételt, akiknek nem voltak - például vallásosságukból adódó - lelkiismereti problémáik a lombikeljárással. 
Az adatok gyüjtésénél és interpretálásánál szem előtt tartjuk az anonimitás szabályát: az adatokat úgy módosítottuk, hogy az interjúalanyokat ne lehessen visszakeresni és beazonosítani (a tanulmányban nem a páciensek valódi keresztneve szerepel). Minden interjúalany aláírt egy informált beleegyezési nyilatkozatot, amiben többek között tájékoztattuk a kutatásról.

$\mathrm{Az}$ eredményeket kvalitatív tematikus elemzés módszerével elemeztük, betartva erre vonatkozóan Braun és Clark (2006) ajánlásait. Az interjúátiratokat, a terepkutatás-jegyzeteinket, valamint az elektronikusan hozzáférhető tartalmakat (pl. honlap) NVivo szoftver segítségével kódoltuk le. Azt vizsgáltuk, hogy milyen ismétlődő tematikus mintázatok figyelhetők meg a korpuszban. Az elemzési kategóriákat részben elmélet és korábbi kutatások alapján, részben induktív módon - a szöveg tanulmányozása alapján - alakítottuk ki. A kódolás több menetben zajlott: egy kezdeti kódolás után összevontunk egyes kategóriákat, megnéztük a kategóriák egymás közötti viszonyait és csoportosítottuk őket (lettek főkategóriák és alkategóriák), új kategóriákat hoztunk létre, amelyekben már az interpretáció is erőteljesebben jelentkezett. Főkategória lett például a gyógykezelési etika, és ez alá a kategória alá lettek besorolva olyan alkategóriák, amelyek ennek az etikának egyes elemeire utaltak. Ezeket az alkategóriákat induktív módon hoztuk létre az elemzett szövegek olvasgatása révén: ilyen alkategória lett például az embrióhierarchia, a végcél fontossága, a jelenlegi helyzet naturalizációja, stb. Figyelembe véve Braun és Clark (2006) javaslatait, különös gondot fordítottunk rá, hogy a kódolás alapos és átfogó legyen, valamint, hogy az elemzés ne pusztán az interjúszövegek összegzéséből, jellemzéséből álljon, hanem ezen túlmutatóan egy interpretációs keretbe ágyazva értelmezze is a szövegeket.

\section{Eredmények}

Az eredmények bemutatásánál először azt az etikai keretet tárgyaljuk, amelynek elemei a legtöbb páciens narratíváját jellemezték: a gyógykezelés-etikai keretet. Ezután bemutatjuk, hogy erre a gondolkodásmódra hogyan erősíthetett rá az a megközelítés, amellyel a klinikai dolgozók részéről találkoztak az interjúalanyok. Végül tárgyaljuk a diskurzusokban megjelenő kisebbségi etikai kereteket.

\section{A páciensek és a gyógykezelési etikai keret}

A vizsgált páciens interjúalanyok beszámolóinak tanulmányozása alapján úgy tűnik, az embriókkal kapcsolatos legtöbb döntési helyzetben az volt a domináns szempont, hogy kezelésük sikerességere vonatkozóan mi a saját érdekük, hogy a kezelés a lehető legkisebb nehézségekkel járjon számukra. Ennek az etikai keretnek a jellemzésére átvesszük a Svendson és Koch (2008) által használ gyógykezelési etikai keret terminológiát. Lehetne azt mondani, természetes, hogy egy páciensnek a saját kezelési érdekei az elsőrendűek, valamint anyagi, munkahelyi, párkapcsolati és 
egészségügyi nehézségeinek minimalizálása, de ahogy Roberts (2007) kutatásnál bemutattuk, ez korántsem szükségszerű. Elképzelhető, hogy egy pácienst más jellegű megfontolások vezéreljenek egyes döntéseinél. Ezt követően sorra vesszük, milyen jellemzők fordultak elő az interjúk során, amelyeket ehhez a domináns etikai kerethez soroltunk.

\section{Embrióhierarchia}

Azt találtuk, hogy a gyógykezelési etikai keretet alkalmazva a kérdezett páciensek többsége az embriókra másként tekintett, mint ahogy az az életetikai megközelítésben jelentkezik. Míg utóbbi minden embriónak egyformán magas értéket tulajdonít, és kivétel nélkül az emberi léthez kapcsolja őket, addig a kérdezettek esetében megjelenő gyógykezelési etikát egyfajta embrióhierarchia jellemezte. Ebben a szemléletben azok az embriók, amelyek közelebb viszik a pácienst céljukhoz, fontosabbak és értékesebbek. Ebben a látásmódban a figyelem középpontjában lévő embriókat jobban összekapcsolják a babákkal. Többnyire az életnek nem egy absztrakt értelmezése jelenik meg, hanem a saját gyerekre fókuszálnak (ennyiben hasonlít a rokonsági etikához). Az embrió nem önmagáért való értékként jelenik meg, hanem értéke ahhoz kapcsolódik, hogy miként tud hozzájárulni a pár céljához. Adott időpillanatban mindig azok az embriók voltak hangsúlyosabbak, amelyek összhangba kerültek ezzel a céllal. A többi embrió, amelyek kiszelektálódtak (akár biológiai, akár egyéb okból), háttérbe szorult. Egy adott embrió a figyelem és a tevékenységek perifériájáról újra a figyelem középpontjába kerülhetett, amennyiben a szerepe átértékelődött a kezelés céljának (baba születése) megvalósításában (például: az olyan embrió, amelyet előbb lefagyasztottak, majd később beültetés céljából felengedtek).

Az interjúalanyok többségénél tehát megfigyelhető volt, hogy az embrió konstruálása képlékeny és folyamatosan változó. Függ a tértől és az időtől, tehát nem statikus és állandó. Különböző módokon beszéltek az embriókról, jellemezték azokat, többek között a következő tényezők függvényében: meghatározó elem az idő kérdése (embrió kora), az embrió aktuális helye (anyaméhen kívül/belül van - megtörtént-e már a beültetés), az embrió egyes jól meghatározott biológiai jellemzői (fejlődik-e, életképes-e), valamint várható szerepe az eljárás végső céljának (baba születése) elérésében.

Azok az embriók, amelyek a beültetés napja előtt leálltak a fejlődésben, vagy bár nem álltak le, de „alkalmatlannak”, „életképtelennek” lettek minősítve, ezért kiselejtezésre kerültek, teljesen háttérbe szorultak a páciensek többségének diskurzusaiban. Különösebben nem foglalkoztak velük, inkább csak külön rákérdezésre beszéltek róluk. Ezeknek az embrióknak nem tulajdonítottak jelentőséget. Sokszor nem is lehetett rekonstruálni, hogy a beültetés napján hány embrió volt, ami nem minősült életképesnek, mert ezek egyszerúen eltűntek az emlékezetükből és ennek megfelelően a diskurzusból is. Sőt a páciensek zavarosan használták, hogy ezek egyáltalán embriónak minősülnek-e. Sokszor a „maradék embrió” kifejezést a páciensek nem 
is ezekre a rossz minősítésú embriókra utalva használták, hanem azokra, amelyek nem kerültek beültetésre, de azért olyan volt a minősítésük, hogy fagyasztásra alkalmasak voltak. Így tulajdonképpen kikerültek az embriók köréből az olyan rossz minősítésű embriók, amelyek nem kerültek beültetésre vagy fagyasztásra:

„Az gyakorlatilag, az semmi, az selejt, tehát azzal nem is foglalkozunk, meg ők se, tehát senki többet harmadszor." (Sarolta)

$\mathrm{Az}$ interjúalanyok zömmel nem értékelték morális dilemmának, hogy egyes kedvezőtlen minősítésű embriók megsemmisítésre kerültek, hiszen azok nem segítették őket céljuk elérésében. Többnyire úgy vélték, az összes „alkalmas”, „életképes” embriót vagy beültették, vagy lefagyasztották. Nem kérdőjelezték meg az embrióbesorolást, beszédmódjukból úgy tűnt, hogy az ismertetéseknek megfelelően ők is megkülönböztetnek életképes és életképtelen, alkalmas és alkalmatlan embriókat. Az életképes/életképtelen, alkalmas/alkalmatlan embriók közötti határvonalat egyértelműnek tekintették, azaz elfogadták a szakemberek klasszifikációját. Azokat az embriókat, amelyek nem kerültek beültetésre vagy lefagyasztásra, egyszerűen értéktelennek tartották. Sőt, ahogy tárgyaltuk, egyes esetekben ezeket még csak nem is tartották embrióknak - ennek megfelelően nem is tulajdonítottak a megsemmisítésüknek komolyabb jelentőséget. Ugyanakkor korábban az embrióminősítés bemutatásánál láthattuk, hogy a jó és nem jó minősítésű embriók között a sikert illetően valószínűségi különbség van. A páciensek ugyanakkor úgy beszéltek e kategóriákról, mintha egy egyértelmű határvonal felett az életképes embriók volnának, a határpont másik oldalán pedig a fejlődési, megtapadási eséllyel egyáltalán nem rendelkezők.

A megkérdezett páciensek az embriók kapcsán a beültetés előtti időszakra vonatkozóan egyfajta elsősorban számokra koncentráló kifejezésmódot alkalmaztak. Beszámolóikban az egyik rendszeresen visszatérő alapkérdés az volt, hogy „Hány darab van belölük?”. Egy idő után azonban, ahogy ezt korábban is jeleztük, többen már nem is emlékeztek pontosan, hogy végül hány embrió nem került beültetésre: ezekkel az embriókkal kevésbé foglalkoztak. Azok az embriók, amelyek nem kerültek beültetésre, a vizsgálatkor nem tartoztak a legéletképesebbek közé, de később még alkalmassá válhatnak a beültetésre - tehát nem nagyon rossz minősítésűek, fagyasztásra alkalmasak - szintén viszonylag háttérben voltak számukra a beültetésre kerülő embriókhoz képest. Voltak, akik nem emlékeztek, hogy egyes lombik ciklusaikban hány embriójuk került fagyasztásra.

„Ez abban a környezetben, meg helyzetben nem ez a fontos... ott az fontos, hogy sikerüljön... és akkor most nem azzal foglalkozik az ember, hogy most, úristen, akkor a többivel mi lesz..." (Tünde)

Úgy tûnt, többen az eljárás során nem foglalkoztak azzal, hogy a maradék embriókkal mi történik, azok teljesen kikerültek a fókuszból. A gyakran emocionális beszélgetések során érezhető volt, hogy több nehezebb és absztrakt kérdésről csak az 
interjúk során gondolkodtak el először. Az alábbi reakció az embriók kutatási célú felhasználási opciójának említése után hangzott el:

„De látod, ez se merült fel, érdekes, hogy mennyire részletesen belemegyünk olyan dolgokba, amik az idő alatt eszembe sem jutottak volna." (Beatrix)

A fenti idézet is azt példázza, hogy ezek az embriók mennyire háttérbe szorulnak.

Voltak olyan esetek is, ahol az interjúalany - bár az elején fontosnak tartotta volna a maradék nem elég jó minőségű embriók lefagyasztását is - arról számolt be, hogy mivel ezt nem engedték meg nekik, utána ők tudatosan próbáltak csak a beültetett és fagyasztott embriókra koncentrálni:

„Igazából meghozták helyettünk, tehát mi hiába hadakoztunk, hogy de mi szeretnénk az összes embriót, hogy de fagyasszuk le, fagyasszuk le, azt mondták, hogy nem lehet, mert nem jó minöségüek, tehát ez meg lett mondva... de erre nem szeretünk gondolni, merthogy ez merült fel, amit nehezen felejt az ember, meg nehezen lép túl rajta, hogy mi lehetett volna, ha, de hát nyilván elfogadja az ember, hogy életképtelen, jó, ennyi, de hát szerintem ez az egyik legnehezebb. Hát, ugye, a többieket nem láttuk, óket csak hírből tudtuk elképzelni, próbáltunk azokra koncentrálni, akik, vagy amik ugye, akikről beszéltek ők, tehát a többit próbáltuk elfelejteni, hogy az nem is volt, és akkor nem gondoltunk arra, hogy több is volt." (Szilvia)

A beültetés kapcsán az interjúalanyok többségének beszámolóiban azok az embriók kerültek a középpontba, amelyekre az orvosok irányították a figyelmüket. Azokról beszéltek, amelyeket már kiválasztottak, és amelyekben az orvosok a legnagyobb potenciált látták. A beültetés pillanata meghatározó volt sokak számára - amíg csak a képernyőn látták kivetítve a beültetendő embriókat, a beültetés sikerére koncentráltak. Utána, amint már beültették őket (már a testükben voltak), már kizárólag arra koncentráltak, hogy megtapadjanak és továbbosztódjanak. Az embriók helyének a szerepét is jól mutatja, hogy a beültetés után többeknél változás volt megfigyelhető a róluk való gondolkodásban. A megtapadás tényét láthattuk sokaknál további határpontnak, innentől kezdve már perszonalizálva, „kis jövevényként” említették az embriókat. Ezzel szemben beültetés előtt, ahogy láttuk, inkább absztraktabb módon, számokban beszéltek róluk. A megszemélyesítés ezen hiánya egyfajta távolságtartást is lehetővé tett számukra, ami főként a már sok csalódást átélő párok esetében volt kiemelkedően fontos. A beültetés utáni éles interpretációs váltást mutatják az alábbi idézetek:

„Aztán utána már megint másként gondolod az egészet, és akkor ott meg már átfordul... a beültetés után, akkor már nyilván én is úgy fogom fel, mint egy kis embernek, de a legjobb és legtudatosabb, amikor már, ugye megvan az eredménye... tehát onnantól indul végül is." (Edina)

A humanizáció tényét hangsúlyozták, a kötődést és az anyai érzések kialakulását fogalmazták meg a beültetés utánra: 
„Félteni kezdtem öket. Amikor először fel kell állni, fel kell öltözni, ki kell ülni a váróba, de hogyan üljek a váróba? Tehát ezek a... ha gyorsan sétálok, az baj, a férjem is mondja, hogy ne is sétáljak, a kocsival bejön, tudod. De... és akkor mondja, hogy majd a kocsival odaáll, de mondom, ne, ennyit lehet sétálni, tehát nem esnek ki ezek a gyerekek szerintem ilyen könnyen, de azért a fejemben ez benne volt. Vagy pl. olyanok, hogy tényleg ugye, amikor bent vannak az embriók, és akkor elkezded ilyen mániákusan olvasni az interneten, hogy hogy kell feküdni, hogy jó legyen nekik." (Karolina)

„Mind a háromnál úgy éltem a napokat, hogy kismama vagyok (a beültetés után)." (Szilvia)

Többen számoltak be arról, hogy beültetés után megváltozott, ahogy szólították egymást a páciensek:

„Meg egymást is viccesen anyukának szólítottuk, tudod ott már a lányokkal. Hát, igen, végül is ez szerintem nekünk már annyi idő után, meg akinek pláne nincs, meg idáig még természetes úton nem jutott el, az azért már nagy sikerélmény, hogy van egy embrió a méhében, úgyhogy igen." (Anita)

A hely (anyaméh) szerepének fontosságára az embriókonstrukcióval kapcsolatban az interjúk azon részében is történtek utalások, amikor azt kértük, hogy vessék össze a beültetés előtti embrión végzett vizsgálatok lehetőségét a magzat vizsgálataival:

„Kint van egy csészében rajtad kívül, lehet, könnyebb úgy eldönteni valamit, mint amikor már benned van és benned növekszik." (Tünde)

Az idézet rávilágít a testen kívüliség és belüliség megélésének különbségére. Azt láthatjuk, hogy egyes interjúalanyok számára az embriókkal kapcsolatos döntéseket sokkal nehezebb meghozni akkor, amikor már bennük növekszik az embrió, mint amikor a testükön kívül van még. A magzatredukció gondolata teljesen felkavaró volt számukra. Ennek magyarázata, hogy azt érezték, a beültetés után hozzájuk tartozik. Bár korábban is egyesek egyfajta tulajdont láttak benne, de az érzelmi kötődés még nem alakult ki olyan erősen, mint beültetés után.

Ugyanakkor a kérdezett páciensek beültetett embriókról való gondolkodásában jelen volt az a mozzanat is, hogy a beültetés nem feltétlenül jelenti azt, hogy a baba világra is fog jönni. Ez különösen azoknál volt érzékelhető, akik már több beültetésen voltak túl. Ezért többen inkább egyfajta lehetőséget láttak bennük, még nem tekintették őket emberként, de már többet jelentettek számukra, mint sejtek puszta halmazát:

„Hát, nekem, még ott nem tudom, olyan vegyes, ott még nem tudom, jó, tudom, hogy egy életkezdemény, de még nem tudom teljesen magamnak tudni." (Gabi) 
Minél közelebb kerültek az áhított célhoz, a gyermekhez, annál egyértelmúbben kimutatható a szemléletben való változás. Egyre inkább emberként, és nem csupán sejthalmazként tekintettek a magzatra. Ahogy bemutattuk, a beültetés után tipikusan megváltozott az interjúalanyok viszonya a magzathoz. Az idő előrehaladtával fokozatosan egyre erősebbé vált a kötődés: minél több időt töltött az embrió az anyaméhben, annál inkább növekedett a fontossága, és ezzel párhuzamosan egyre közelebb kerültek az interjúalanyok szemében az emberi státuszhoz, és ennek megfelelően egyre távolabbra a biológiai megítélésük alapján kialakított sejthalmaz kategóriától. Az interjúalanyok az embrió megnevezésére az idő és a hely függvényében különböző metaforákat találtak ki. Ez kapcsolatban állhat azzal, hogy milyen ontológiai státusszal ruházták fel az embriókat, valamint az emocionális elmélyülés mértékével. A beültetés előtt elsősorban a vizualitást tükröző szóképekre támaszkodtak, a „buborék” vagy a „virág” metaforákat használták, hiszen a beültetés előtt álló embriókat ilyennek látták a monitoron. A „babám” szót elsősorban a már beültetett embriókra használták, itt már jóval magasabb az érzelmi bevonódás mértéke, így természetesebb a megszemélyesítő megnevezés. A kettő közötti átmenetre példa az „életkezdemény” megnevezés. Ebben az esetben már többnek látták az embriót, mint sejtek halmazának, ám még nem ruházták fel emberi tulajdonságokkal, inkább lehetőséget láttak benne.

Az embrióhierarchiát azoknál a pácienseknél kevésbé lehetett megfigyelni a diskurzusban, akiknek olyan kevés embriójuk volt, hogy épp csak be tudtak ültetni nekik, de nem maradt több (vagy lefagyasztásra alkalmas több).

\section{Döntés arról, igénybe vesznek-e lombikkezelést}

A gyógykezelési etikai keretben, még ha a döntés érintette is az embriót, a választás indoklásában nem jellemző, hogy szerepeltek az embrióhoz kapcsolható szempontok - inkább a páciens kezelésének sikeressége és az anyagi és egyéb költségek minimalizálása jelent meg. Az embrió státuszához kapcsolódó morális kérdések, dilemmák a háttérben maradtak, és sokszor úgy tűnt, ezekről a szempontokról nem is igazán gondolkodtak el mélyen, részletekbe menően a kezelésük folyamán. A gondolkodásukban elsősorban a racionális szempontok kerültek előtérbe. A gyógykezelési etikai keret jelentkezett tipikusan, amikor arra kérdeztünk rá, mi okozott érzelmi nehézséget, dilemmákat az eljárás választásakor és az eljárás során. Hasonlóan, amikor arról érdeklődtünk, hogy milyen szempontokat vesznek figyelembe, amikor azon gondolkodnak, folytatják-e a kezelést.

Elsősorban a sikertelen beültetések okozta lelki folyamatok és átélt traumák okoztak számukra érzelmi nehézséget. Az érzelmek intenzitása növekedett a sorozatos sikertelenségek tapasztalásával.

„Még az első 2-3 után az ember még úgy van vele, hogy hát nem sikerül, nem sikerül, de a negyedikbe, ötödikbe, hatodikba, hetedikbe úgy belemenni, hogy ott van a kudarc élménynek az esélye, az úgy baromi nehéz volt. Az utolsóba már nagy 
erőfeszités volt, hogy beleugorjak. Vagy beleugorjunk. Sőt, most már azt mondom, hogy többet már nem is mernék. Én annyira kiégtem, vagy nem is tudom, hogy hogy mondjam, hogy így rémálom, tehát hihetetlen. Gyomorideg, gyomorgörcs, egy hónap biztos stressz. Annak ellenére ugye, hogy engedd el, lazulj el, ne foglalkozz vele. Tehát nem görcsben álltam egész nap, de ez a bizonytalanságérzés, hogy lesz-e gyerek vagy nem lesz-e gyerek, ez kikészít. Ha mondanák, hogy nem lehet, ne is próbálkozzak, abba ugye bele lehetne törödni, de így, hogy nem mondanak semmit, csak hogy próbálkozzak." (Hanna)

Sokan az információhiányt élték meg rosszul. Úgy gondolták, hogy fokozottan aszimmetrikus a viszony az egészségügyi szakemberekkel. Emocionálisan megviselte őket a tájékoztatás hiánya. Kiszolgáltatottságról, összezavarodottságról és izolációról számoltak be. Mindezek mellett azonban az egyik legnehezebben kezelhető lelki tényezőt a fizikai megpróbáltatás, a hormonstimuláció okozta számukra; olyan mellékhatások és fizikai elváltozások jelentek meg rajtuk, amelyeket nőként nehezen tudtak elviselni. A hormonstimuláció miatt megváltozott a külső megjelenésük, és a folyamatos fizikai tüneteket (gyakran fájdalmat) okozó mellékhatások megviselték a pácienseket. A párkapcsolatukra is nagy nyomást helyezett a kezelés (mind szexuális téren, mind emocionálisan megváltozott kapcsolatokról meséltek), és anyagilag is megterhelőnek érezték az eljárást (állami támogatás esetén is).

A fentieknek megfelelően, a kezelések folytatását befolyásoló tényezők között is elsősorban a hétköznapi életet, mindennapi rutinjukat érintő témák merültek fel. Ilyen volt például, hogy hogyan lehet összeegyeztetni a beavatkozást a munkával (itt mind anyagi, mind karrierszempontok felmerültek), mennyire támogató ebben a munkaadó, vagy hogy ha már van gyermek a családban, akkor őt hogyan érintené, ha érkezne egy újabb családtag (rokonságetikai keret). Foglalkoztatta őket a párkapcsolatukra gyakorolt további, elhúzódó hatás is. Annak mérlegelésénél, hogy újból részt vennének-e ilyen kezelésen, a hormonstimuláció okozta mellékhatásokat is kiemelték. A próbálkozások számát illetően a beültetés anyagi vonzata is fontos volt számukra, de többen kiemelték a kudarcélmények feldolgozását és a stresszt is. „Egyelöre semmi, az idö a mérvadó, tehát hajt az idő minket, mert minél idôsebb az ember, annál nehezebb... aztán, hogy mi lesz az ötödik alkalom után, az teljesen az anyagiakon múlik, teljesen." (Szandra)

A fenti idézet is a gyógykezelési etikai keretnek megfelelően a páciens szempontjaira teszi a hangsúlyt.

\section{Döntések a beültetésre kerülö embriók számáról}

A beültetésre kerülő embriók számát illetően a gyógykezelési etikának megfelelően két fő szempontot hangsúlyoztak. Egyrészt, hogy növeljék annak esélyét, hogy sikeres terhesség jöjjön létre, másrészt, hogy ne tegyék ki magukat túlzott egészségügyi 
kockázatnak esetleges többes terhesség során. Befolyásoló tényezőként jelentkezett még esetenként az is, hogy hány gyereket szeretnének: hiszen mi történik, ha két beültetett embrió közül mindkettő beágyazódik. Beültetett embriók esetében olyan morális dilemma merülhet fel, hogy amennyiben három embrió került beültetésre, és meg is maradnak, szükségessé válhat egy további beavatkozás, hogy végül csak két embrió maradjon (embrióredukció, vagy amennyiben később történik, magzatredukció) a hármas terhesség fokozott kockázatai miatt. Sokaknál, úgy tủnik, amiatt nem merült fel ez a morális dilemma, mert a két embrió tűnt a szokásos útnak. Ennek egyik oka az orvos ajánlása - azaz, a klinika kommunikálása, illetve sokan arról számoltak be, hogy nem is tudtak róla, hogy létezik magzatredukció. Ennek megfelelően, amikor arról gondolkodtak, hány embrió kerüljön beültetésre, elsősorban azt gondolták végig, hányas terhességet tudnak egészségügyileg elbírni. Nem volt olyan interjúalanyunk, akin magzatredukciót hajtottak volna végre.

\section{Döntés, legyen-e fagyasztás}

Amikor az embriók fagyasztásáról gondolkodtak, az azzal kapcsolatos döntéseiket hozták meg, beszámolóik szerint nem életetikai megfontolások alapján mérlegeltek (vagyis nem merült fel, hogy morális státuszuk miatt ne kerüljenek friss embriók elpusztításra). Szintén nem volt jelen a rokonságetikai keret a döntéshozatalnál, ahogy ezt az ecuadori páciensek esetében láthattuk (Roberts 2007), hanem a gyógykezelés-etikai keretnek megfelelően azt mérlegelték, hogy számukra, páciensek számára mi lenne az optimális kezelés céljaik teljesülése szempontjából. Főként egészségügyi és anyagi szempontok merültek fel: nem kívánták kitenni magukat újra hormonstimulációnak - a költségek és a káros mellékhatások miatt:

„Még a fagyasztottnak annyi az előnye szerintem, hogy ugye nem egy, nem egy olyan, nem egy ciklusban, tehát, hogy természetes ciklusban kerül beültetésre egy fagyasztott embrió, és ezért a szervezet tud kicsit pihenni, tehát nem úgy, mint egy ilyen egész hormonkezelés után" (Zsófia)

Bár a fagyasztási döntés érinti, hogy elpusztításra kerülnek-e embriók vagy sem, a fő érvrendszer a döntés kapcsán nem tért ki az embriókra, hanem a páciensek egészségi szempontjaira koncentrált.

\section{A végcél fontossága}

Interjúalanyaink elbeszélése szerint az eljárások során végig az áhított cél elérése, a kisbaba motiválta, vitte őket előre az útjukon. Ezt a fajta gyógykezelési etikát tehát a végeredmény kiemelt fontossága jellemezte. Láthattuk korábban, hogy a magyar társadalomban nagyon fontos értéknek számít, hogy valakinek saját gyereke legyen (Miettinen-Szalma 2014; Szalma 2014), ez az interjúalanyainknál is fontos tényező volt, úgy érezték, hogy a saját gyerekért akár nagy áldozatokat is hajlandóak vállalni. 
„Fogalmad sincs, hogy minek veted magad alá, ott olyan szinten akarod, olyan szinten csak ez lebeg elötted, ez az erôs, elszánt akarat, hogy teneked legyen babád, hogy mindent félreteszel, fogalmad sincs arról, hogy ezzel te a szervezetedet mekkora mértékben mérgezed, mételyezed." (Sarolta)

A magas kockázatokkal szembeállították a gyermek nélküli életet, amit annyira elképzelhetetlennek és elviselhetetlennek véltek, hogy ez a sok mellékhatás miatti szenvedést is felülírta.

„Hát, nekem pontos félszem van egyébként a hormonkezelésektől, nekem édesanyám tavaly halt meg petefészekrákban, tehát nyilván az, hogy fiatalon, viszonylag fiatalon, nyilván az, hogy ez az állandó stimulálgatás ez azért nem tesz jót, ezzel tisztában vagyok. Ugyanakkor meg azt gondolom, hogy oké, viszont egyszerüen gyerek nélkül meg nem érdemes élni, tehát, hogy most azt hiszem, könnyen beszélek, de ha ezt az okozza, ez a sok hormonkezelés, esetleg egy nem tudom, egy korábbi halált okoz, ezzel mondjuk esetleg tisztában vagyok, de, de még akkor is azt mondom, most persze mondom, könnyen beszélve, de hogy megéri, ha ennek az lesz a vége, hogy baba. De azért olyan, ami kiverte volna a biztositékot, ilyen nincsen, azért nincsen, mert ez a cél lebeg a szemem elött, és addig nincs olyan szerintem, ami nagyon ki tudná verni a biztosítékot." (Zsófia)

Sokszor a beültetés napján kapják meg a páciensek a maradék embriók sorsáról szóló nyomtatványokat, ekkor azonban - mint láthattuk - más foglalkoztatja őket, hiszen a beültetés a kulcsesemény a végcél elérésében:

„Ott és akkor... nem vagy igazán erre úgy felkészülve, hogy megfelelöen átgondolt és a megfelelö döntést hozz, hanem ott hozol gyorsan, ilyen, ilyen, mintha lottóznál, én úgy gondolom, mert, meg nincs is úgy rá időd, nem adják oda azt a papirt, hogy hozd haza, és legközelebb egy hét múlva jössz, és hozd vissza kitöltve, és rágd át, hanem ott várakozás közben történik, töltetik ki veled, na, most ha ezt odaadnák egyik hétről a másikra, akkor te teljesen más fejjel, gondolkodással döntesz ezekröl a dolgokról." (Sarolta)

„Amit aláírtunk, körülbelül 5 másodperc volt az egész, mondom, annyira gyorsan történik itt a klinikán minden, merthogy annyira sok a meddő pár, hogy egyszerüen, föleg néha olyan érzésem volt, hogy arra nem emlékszem, hogy levetkőztem egyáltalán, volt-e vizsgálatom bent." (Vera)

Mivel a fagyasztási döntést legkésőbb a beültetés napján meg kell hozni, érthető, hogyha aznap kell leadni ezt a nyomtatványt - viszont akár lehetne az is, hogy ezt a páciensek már korábban megkapják, hogy tudjanak gondolkodni rajta.

\section{Az aktuális helyzet naturalizációja}

Több interjúalanynál megfigyelhető volt az aktuális helyzet naturalizációja: úgy vélte, ha gyereket szeretne, akkor nincs más választása, mint a lombikeljárás. A lehe- 
tőségek közül is az a megfelelő módja, ahogyan az eljárást rajta alkalmazták - nem kérdőjelezték meg a klinikák, orvosok javaslatait, az eljárásokat, a protokollt:

„Dátumot is el tudod dönteni... más döntésed meg gyakorlatilag nincs, mert ez az egy utad van, hogyha gyereket szeretnél" (Tünde)

A gyermekvállalás más lehetőségeivel nem foglalkoztak, a donorsejtek vagy donorembriók használata, illetve az örökbefogadás gondolata addig nem merült fel interjúalanyainkban, amíg nem járták végig a lombikeljárás nyújtotta lehetőségeket. Azokat a megoldásokat, utakat helyezték előtérbe, amelyek lehetővé tehetik számukra, hogy a saját sejtjeiket használva, vér szerinti gyermekük szülessen Nem merült fel az interjúk során sem opció a jelenlegi számos maradék embriót eredményező lombikeljárások alternatívájaként másfajta lombikeljárási protokollra - csupán az orvosok által prezentáltakra fókuszáltak. Nem gondoltak arra, hogy olyan megoldásokat alkalmazzanak, ahol kevesebb maradék embrió keletkezik (pl. hogy etikai okból lefagyasszák a petesejtjeiket, és egyszerre csak egy részük kerüljön megtermékenyítésre, vagy ne legyen hormonstimuláció, aminek eredményeképpen kevesebb embrió hozható létre, vagy olyan opció kérése, hogy kevés embriót hozzanak létre, és az összes létrehozott embrió kerüljön beültetésre - ezek az opciók mind jelentősen csökkentenék a sikerességi esélyeket, és nem illeszkednek a domináns gyógykezelési keretbe). Mivel úgy érezték, nincs más választási lehetőségük a számukra kiemelten fontos cél elérésére, ez szintén hozzájárult a maradék embriók körüli dilemmák háttérbe szorulásához.

\section{A vallás megélése}

A gyógykezelési etikát alkalmazó vallásos interjúalanyok a vallást úgy élték meg, hogy az összeegyeztethető a lombikeljárással, és hitük még segítheti is őket az eljárás alatt. Az interjúalanyok közül sokan kereszténynek, többen katolikusnak vallották magukat, még ha többnyire nem is jártak rendszeresen templomba. Vallásosságuk ellenére sem érezték úgy, hogy a kezelés előtt meg kellene ismerniük, mi az egyház álláspontja a lombikeljárással kapcsolatban, vagy hogy az egyház hivatalos, alapvetően életetikai szempontokat középpontba helyező álláspontját kellene követniük az eljárás során hozott döntéseik során:

„Az, hogy a vallás ezt elutasítja, igazából nem is nagyon néztem utána, vagy nem is folytam bele, én ezt abszolút nem fogom azért elutasitani, mert a vallás ezt mondja, nekem egy célom volt, hogy legyen gyerekem, és így utólag azt mondom, hogy teljesen mindegy, hogy hogy... nem fogják megkülönböztetni, hogy lombikbaba, én ezt büszkén felvállalom a mai napig, kereszténységröl ennyi." (Beatrix)

A vallás inkább akkor jelent meg az interjúk során, amikor néhányan arra utaltak, hogy milyen mértékben vágytak a kisbabára. Az eljárás sikerességéért voltak, akik imádkoztak is. 
„Hát amikor leszívták, ugye, akkor utána hogy hát így mindig imádkoztam, hogy osztódj, vagy megtermékenyüljenek, meg hogy osztódjanak." (Kriszti)

Az életetikai szempontok mellett kiállókat radikálisoknak ítélték meg. Mivel interjúalanyaink közül azok, akik vallásosnak vallották magukat, zömével úgy nyilatkoztak, hogy „a maguk módján” élik meg a vallásosságukat, beszámolóik szerint nem okozott számukra nagy dilemmát a lombikeljárásban való részvétel. Egyes interjúkban vallási fanatikusnak konstruálták meg az olyan nézetekképviselőket, akik vallási okból elvetik a lombikeljárást.

A szükebb, tágabb környezet:

Zömében úgy tapasztalták a páciensek, hogy a gyógykezelési etika jelentkezik a szűkebb, tágabb környezetük és a klinikai dolgozók esetében is. Hazai internetes fórumokon is a gyógykezelési etika volt a domináns (Bauer 2014a).

Ha a tágabb környezetet vizsgáljuk, azt látjuk, hogy a legnagyobb hazai felekezettel rendelkező katolikus egyház, valamint a Vatikán álláspontja - többek között életetikai okokból is - többnyire elutasító a lombikeljárás kapcsán (Prainsack 2006). A katolikus egyház ugyanakkor hazánkban nem lépett fel aktívan a lombikeljárások ellen a kutatási időszak végéig, sőt még az embrionális őssejtkutatás ellen sem, ami szintén a pár napos embriók kérdéskörét állíthatta volna a figyelem középpontjába (ahogy jeleztük, Veres András püspök támadása a lombikeljárás ellen csak a kutatásunk után jelentkezett). A hazai médiában sem jelentek meg érdemi viták az embriók kérdéskörével kapcsolatban, így az embrió körüli lehetséges életetikai szempontokról sem (a lombikeljárásokról is többségében egy-egy híresség, pl. Ördög Nóra kapcsán volt számottevő diskurzus). A társadalmi nyilvánosságban zajló vitáknak a hiánya is szerepet játszhat abban, hogy a maradék embriók körüli potenciális dilemmák többnyire nem merültek fel a páciensek beszámolóiban.

\section{Az egészségügyi dolgozók és a gyógykezelési etikai keret}

A szakirodalmi áttekintésnél láthattuk, számos kutatás kimutatta, hogy a páciensek nézeteit jelentősen befolyásolhatja az egészségügyi személyzettől kapott információ (Memmi 2012; Fannin 2012), így releváns megvizsgálni, hogy a klinikai dolgozók részéről milyen hozzáállással találkozhatnak a páciensek. Az Adatok és módszerek részben kifejtettük annak indokát, hogy ezt a befolyást miért elsősorban az interjúalanyok beszámolóiból utólag igyekszünk rekonstruálni, illetve kisebb részben egy klinikán végzett korlátozott megfigyelések kapcsán. Itt újra hangsúlyozzuk, hogy módszertani szempontból nem ez lett volna az ideális kutatási design, de együttérzés, emberségesség és etikai megfontolások alapján eltekintettünk a klinikai dolgozó-páciens interakciók megfigyelésétől.

Azt találtuk, hogy az interjúalanyok beszámolói szerint a klinikai dolgozók részéről a gyógykezelési etikának megfelelő megközelítéssel találkoztak. 
Az elmesélt történetek és helyzetek alapján a klinikákon hangsúlyosan jelentkezett az embrióhierarchia - mind a nyelvi kódokban, mind a vizuális megjelenítés szintjén. Egyes embriók hangsúlyosan szerepeltek a klinikai kommunikációban a páciensek felé, míg mások háttérbe szorultak és/vagy kevésbé értékesként lettek kategorizálva. Az intézeti bánásmódban az embriók kapcsán szintén jellemző volt az embrióhierarchia: azok az embriók álltak a középpontban, amelyek leginkább sikerrel kecsegtettek, hogy a pácienseknél sikeres terhességhez vezessenek, azaz amelyek legközelebb álltak a terhességi célhoz.

A páciensek elmondásaiból az derül ki, hogy az egészségügyi személyzet sok helyen a beültetés előtti embriók esetében egy számokra támaszkodó leírást alkalmazott. Úgy tűnik, a számokban megnyilvánuló jellemzés internalizálása segített a pácienseknek a kötődésük kontrolljában. Megadta a lehetőséget arra, hogy érzelmileg elhatárolódjanak azoktól a rossz minősítést kapó embrióktól, amelyek kiesnek a terhességi zónából. Sok esetben úgy tűnt, hogy a páciensek narratíváihoz hasonlóan a klinikai kommunikációban is határpontnak számít a beültetés. Többen beszámoltak arról, hogy megváltozott a szakemberek és a személyzet viselkedése, hozzáállása. A beavatkozás után egyes helyeken lényegében már kismamaként kezelték a pácienseket, azt kommunikálva irányukba, hogy szinte elérték céljukat. Többen utaltak arra, hogy olyan ultrahangképet kaptak hazavitelre, mint a várandós nők a terhesgondozáson. Ez erősíthette a beültetés egyenlő sikeres beültetés, illetve embrió egyenlő baba asszociációkat a beültetett embriók esetében, amelyet a korábbi szakaszban részleteztünk. Az anyaméhbe helyezett embriók előtérbe helyezése is rávilágít arra, hogy egyfajta ontológiai váltás figyelhető meg az eljárás különböző szakaszai között. A váltás felismerhető nemcsak abban, ahogy az embriókat kezelik, hanem abban is, ahogy beszélnek róluk ezeken a klinikákon a beültetés előtt és után, az embrió helyének függvényében (előtte olyan szakkifejezéseket használtak, amelyek absztraktak és ismeretlenek voltak, és mint speciális organizmust konstruálták meg az embriót, utána pedig mint egy tényleges terhesség kezdetéről, egy potenciális babáról beszéltek).

„Akárkit kitoltak, mindenki kapott egy ultrahangképet, és mindenkit úgy toltak ki, hogy üdvözlik a kismamát... és akkor mindenki tök boldogan szorongatta a képet, hogy na, itt vannak a kisbabáim." (Szandra)

Befolyásolhatja a páciensek képét és hozzáállását, hogy miről kapnak információt a klinikán, és melyek azok a tényezők, amelyekről egyáltalán nem is esik szó. Szóbeli tájékoztatás elmaradása esetén az is érdekes lehet, hogy milyen szintű információkat biztosítanak írásban. A döntések meghozatala során szintén számottevő, hogy egy adott kérdés mérlegelésére mennyi időt ad a klinika - azonnali döntésre van szükség, vagy adnak időt a gondolkodásra, a konzekvenciák valódi mérlegelésére. A páciensek elsősorban a beültetésre kerülő embriókról kaptak információt, a klinikai dolgozók ezeket jellemezték különböző tulajdonságaik alapján (elsősorban számok- 
ra támaszkodó kommunikációval): milyenek, hogyan osztódtak, hány sejtesek stb. A fagyasztott embriók tulajdonságait már nem jellemezték, és azokat az embriókat sem, amelyek sem fagyasztásra, sem beültetésre nem kerültek (de pl. megélték a beültetés napját, csak nem voltak elég jó minőségűek a fagyasztáshoz). Ezek az embriók jellemzően eltűnnek a páciensek spontán rekonstrukcióiból:

„Teljesen háttérben voltak, mintha nem is léteznének innentöl kezdve, ki lett mondva, hogy ők nem." (Szilvia)

A beültetésre nem kerülő, maradék, fagyasztásra alkalmasnak minősített embriók sorsáról a páciensek csak nyomtatványt töltenek ki, és általában a későbbiekben sem zajlik face to face kommunikáció az egészségügyi személyzet és a páciensek között a felhasználni tervezett maradék embriókhoz kapcsolódó további lehetőségekről sem. Az orvossal tipikusan nem beszélnek a páciensek arról sem, hogy mi legyen a fagyasztott maradék embriók sorsa, amelyek felhasználása már kétségessé vált például sikeres gyerekszülés miatt.

Lényeges lehet az embriók megítélése szempontjából, hogy míg egyes embriókat megmutattak képen vagy monitoron a pácienseknek, a többi, rosszabb minősítésű embrió „láthatatlan” maradt számukra. Az a tény, hogy a beültetésre kerülő embriókat a páciensek sok esetben a beültetés előtt megnézhették monitoron vagy képen, a hangsúlyt a beültetendő embriókra helyezi - erősebb kötődéshez vezethet. Ahogy írtuk, egyes interjúalanyok a beültetés után ultrahangképet is kaptak a beültetett embrióikról. Az ultrahangkép anyaméh + embrió kombinációja már a terhességgel kapcsolatos asszociációkat keltheti, hiszen ilyen képeket a kismamák szoktak kapni - ezzel is erősítve a beültetés körüli értelmezési határvonalat. Mindezt egyes esetekben azzal az is megerősítették, hogy megváltozott a klinikán tapasztalt bánásmód: a pácienseket ekkortól már kismamaként kezelték.

A páciensek úgy érzékelték, hogy a klinika elsősorban a sikeres beültetéseket hangsúlyozza. Közlésbeli különbségekről számoltak be a sikeres és sikertelen beültetések esetében: sikertelen beültetés után sokszor elmaradt a személyes találkozás, nem volt konzultáció. Az embrióhierarchiában ezek az embriók veszítettek jelentőségükből. A jó hírt az orvos inkább személyesen közölte. Ezzel szemben a rossz hírek bejelentését inkább az asszisztensre bízták, vagy a megindult havi vérzés tette egyértelmúvé a beültetés sikertelenségét. Alábbi idézet is az eltérő orvosi kommunikációt mutatja be a sikeresség függvényében:

„Hát, Edina, sajnos ez most nem sikerült, három hónap múlva kellene visszajönni, és elkezdeni... olyan személytelen volt, padlót fogtam... a módszer, ahogy közölték velem... amikor sikerült, behivott a doki az irodájába... teljesen más volt, és nyilván én úgy gondolom, hogy a sikertelenséget is így kell/kellene közölni, hogy behív, és négy fal között, mint hogy a folyosóról odahív egy nyitott ajtóhoz, és így közölteti az asszisztensnöjével." (Edina) 
Egyes klinikákon a már megszületett babák képeivel díszítik a folyosókat, ami szintén az áhított célt helyezi a vizuális fókuszba.

Vannak arra utaló jelek, hogy a klinikai kommunikációs gyakorlat hatással lehet arra, hogy egyes embriók eltűntek a páciensek diskurzusaiból. Bemutattuk, hogy a pácienseknél háttérbe szorulnak a beültetésen felül megmaradt nem megfelelő minősítésű embriók, és hogy sokszor ezek vagy határozottan életképtelen, alkalmatlan embrióknak minősülnek, vagy egyes esetekben nem is tekintik őket embrióknak. A megfigyelt klinikán azt találtuk, hogy a klinikai kommunikáció is csúszkál a tekintetben, hogy mire használja az embrió kifejezést is mire nem. A klinika kommunikációjából is sokszor eltűnnek azokat az embriók, amelyek megmaradtak a beültetés után, de lefagyasztáshoz nem elég jó minősítésűek. A klinikai szóhasználatban (honlapon, ủrlapokon, dolgozói interjúban) a maradék embriók sokszor azokat a beültetésen felül megmaradt embriókat jelentik, amelyek elég jó minősítésűek, hogy fagyasztásra kerüljenek. Ezzel ugyanakkor kizárják a rosszabb minősítésű maradék embriókat az embriók köréből. Miközben tudunk olyan esetekről is a klinikán, ahol a páciens csak ilyen rosszabb minősítésű embrióval rendelkezett, és beültették - ott az ugyanilyen minősítésű embrió nem tûnt el a diskurzusból, embrióként hivatkoztak rá. Úgy tủnik tehát, legalábbis ezen a klinikán, hogy megfigyelhető a klinikai dolgozók részéről egyfajta ontológiai manipuláció, amikor is tehát egy entitást másként kommunikálnak lényegileg aszerint, hogy milyen sorsot javasolnak számukra.

Bár sok intézményről mondták interjúalanyaink, hogy jellemző a gyógykezelési etika, az is megfigyelhető volt, hogy nem mindenhol tudott az embrióhierarchia érvényesülni, hiszen előfordult, hogy túl kevés figyelem, idő jutott a páciensekre. Egyik fontos eleme a gyógykezelési etikának, hogy a beültetésre kerülő embriók kerülnek a középpontba, ezekről beszél az egészségügyi személyzet a pácienseknek, ezeket mutatja meg nekik, illetve a beültetés után ezekről kapnak képet. Voltak esetek, amikor ez sem tudott érvényesülni, mert „futószalagszerü” volt a bánásmód, és olyan kevés idő jutott az orvos-páciens interakciókra, hogy nem kaptak információkat ezekről az embriókról sem. Olyan tapasztalatokról is beszámoltak, hogy egyes helyeken addig nem kezelték kismamaként a pácienseket, amíg a terhességük el nem érte a tizenkettedik hetet.

\section{Kisebbségi etikai keretek}

A domináns gyógykezelési etika mellett egyes döntéseknél más etikák is előfordultak egyes interjúalanyok beszámolóiban.

Az interjúk alapján vannak arra utaló jelek, hogy egyeseknél, bár a be nem ültetett friss embriókkal kapcsolatos döntéshozatal során nem jelentkeztek életetikai szempontok, a fagyasztott embriók tárolásának meghosszabbításáról születő döntések folyamán felmerülhetnek ilyen megfontolások is. Volt néhány olyan interjúalany, akiknek már több évvel azelőtt született gyermeke lombikeljárással, és nem terveztek további terhességet, így amikor felvetették számukra a lefagyasztott 
embriók megsemmisítésének lehetőségét, akkor merült csak fel az embriók sorsával kapcsolatos etikai dilemma. Több interjúalany pedig akkor említett kifejezett rákérdezésre dilemmákat, amikor a fagyasztott embriók sorsának témájára került elő. Interjúalanyaink ezekben az esetekben sem érezték azt, hogy a felengedésük beültetés nélkül „gyilkosság” lenne. Ugyanakkor volt olyan, aki ebben a helyzetben kezdte el érezni a súlyát annak, hogy milyen komoly döntést kell meghoznia. A fagyasztott embriók felhasználása kapcsán az egyik fontos, vagy mondhatjuk a legfontosabb szempont, hogy a család számára jó lenne-e egy kistestvér (ami egyfajta, a Roberts [2007] tanulmányától eltérő rokonságetikai keretnek tekinthető). Emellett komoly dilemmaként jelent meg, hogy kitennék-e testüket és lelküket a lombikeljárás nehézségeinek (gyógykezelés-etikai keret). Volt, aki éppen az utóbbi miatt kifejtette, hogy jobban örülne, ha mégis spontán esne teherbe, mint ha a meglévő fagyasztott embrióival kerülne sor lombikra, és úgy születne testvére a gyermekének. Ezzel szemben elképzelhető ugyanakkor, hogy a fagyasztott embrióval rendelkezők jobban hajlanak arra, hogy részt vegyenek még egy lombikciklusban, hogy bővítsék a családot. A nehéz döntéshozatal elhalasztása is egyfajta megküzdési stratégiaként jelentkezett.

„Nehéz megint, pont nyáron, amikor nem tudtam eldönteni, hogy tovább fagyaszszák-e, és nem az összeg miatt nem tudtam eldönteni, hanem mert nem tudom, hogy szeretnék-e még egy babát; ha igen, akkor mikor. Most afelé hajlok, hogy szeretném még megpróbálni. De bennem volt, hogy azok ott le vannak fagyasztva, és nem akarom, hogy hirtelen megszúnjön. Azt gondolom, hogy az ott már valami kis életkezdemény. Nem olyan, hogy ha nem fizetem be, akkor meggyilkolom öket, nem ilyen drasztikus. De én rendelkezem a sorsukról, nem feltétlen nevezem öket embereknek, de valahogy a tudat, hogy mégis te döntesz leendö emberekröl... sokat kellett rajta gondolkodnom. Ezért is, meg mert nem tudtam, hogy mikor akarom folytatni, és így idôt nyertem magamnak is a döntésre. [...] Nem tudtam meghozni a döntést, hogy mi legyen az embriókkal, nem tudom azt mondani, hogy nincs rájuk szükségem, de azt se, hogy most van." (Tünde)

Ezt a fajta megközelítést tekinthetjük egyfajta „puha” életetikai megfontolásnak is. Míg a szigorú értelemben vett életetikai szemléletben az embrió elpusztítását mindenáron el kell kerülni, ezt a rugalmasabb verziót az jellemzi, hogy lehetőség szerint el kell kerülni a megsemmisítését, ugyanakkor a fagyasztott embriót nem tekinti emberrel azonos morális státuszúnak.

Az eljárás megkezdése előtt és az első eljárások során az interjúalanyok közül többen kevés információval rendelkeztek arról, hogy mi vár rájuk, és milyen döntéseket kell majd meghozniuk. Az, hogy sok páciens kevés információval rendelkezett és mindig az adott fázisra koncentrált, oda vezethetett, hogy kevésbé gondoltak bele, mi történik, ha a sikeres eljárás után maradnak embrióik. Ahogy lépésről lépésre haladtak végig az asszisztált reprodukciós eljárások során, úgy szereztek a 
tapasztalataik során információkat, tudást. Az egyik konzultációról mentek a másikra, minden vizsgálatot egy másik követett, egyik gyógyszeres kezelést felváltotta egy újabb, vagy éppen egy injekciókúra. Ezek során végig arra figyeltek, mit kell tenniük az éppen aktuális szakaszban, hogy megfelelően és helyesen kövessék az orvosi utasításokat. A lépésről lépésre való haladás miatt a páciensek figyelmének fókuszában mindig az állt, hogy mi következik, történik éppen az adott szakaszban. Ez alól kivételt csak a végső cél, a terhesség jelentett, ami mindvégig fókuszban volt. Az út során nem azon volt a hangsúly, mi történhet a jövőben, ha esetleg maradnak életképes fagyasztott embriók. Sokak számára, akiknél még nem járt sikerrel a lombikeljárás, az még ráadásul csak egy lehetőségként merült fel, hogy maradnak a végén életképesnek minősített fagyasztott embrióik, amelyeket végül nem használnak fel. Az adott szakaszra fókuszálás jelenségét jelzi az is, hogy a maradék fagyasztott embriók sorsáról szóló dilemma elsősorban azoknál jelentkezett, akik már több éve túl voltak sikeres lombikeljáráson, és csak azután gondolkoznak el a kérdésről, hogy levelet kaptak az intézménytől, amely döntést kért a tárolás meghosszabbításáról. Ahogy láttuk, a végső döntés, a megsemmisítés kérdése még ekkor is sok évig elhalasztható, amennyiben meghosszabbítják a tárolást.

$\mathrm{Az}$ interjúalanyok körében néhány esetben volt csak megfigyelhető az életetikai felfogás még úgy, hogy zajlottak a lombikeljárásaik. Egy olyan eset volt köztük, aki emiatt másfajta menetet is kért (az idézetből látszik, hogy az absztrakt életetika mellett az embrió, mint saját gyerek felfogás is jelentkezik):

„Dilemmát okozott nekem az, az elejétôl kezdve egyébként, hogyha megtermékenyítenek sokat, már pedig ugye ök azért csinálják ezt, hogy a női szervezetet ne terheljék le annyira ezzel a sok hormonnal újra és újra, ha esetleg az elsö nem jön össze, hanem a fagyasztáshoz hozzá tudjanak nyúlni, ami egy kényelmesebb eljárás, viszont én azt kértem is a dokitól, hogyha lehetséges, akkor nálam ne így müködjön, hanem inkább kevesebb hormonnal, kisebb dózisban, és akkor én inkább mindig alávetem magam ennek az egésznek, mint az, hogy most egy tucatnyi embriót lefagyasztanak, és akkor abból, és, és az okozott nagy fejtörést, hogy mi van akkor, hogyha, ha egy csomó megmarad, tehát mindig azon gondolkoztam, hogy én addig fogok visszajárni, míg az öszszest vissza nem ültetik, nekem ez volt a teóriám, ha most 15 lesz, akkor én igenis viszsza fogok menni az utolsóért is, merthogy számomra az ugyanúgy a saját gyerekem... Egy fagyasztott embriót is ugyanúgy fel tudnak támasztani, és akkor az ott már élet. Szóval igazából véve lényegében nekem ez, tehát én nem tudtam olyan tárgyilagosan tekinteni, elvonatkoztatni attól, hogy ő igazából egy emberi lény, akármilyen furán hangzik. Legalábbis ez az én nézôpontom" (Vera)

A kutatási célú adományozás esetén egyrészt a kutatás fejlődése merült fel egyfelől mint etikai keret, másrészt az altruista szemlélet, mások segítésének a lehetősége. A kutatás előnyéhez sorolták, hogy a felajánlással értelmet nyer a létrehozásuk, és hogy ezzel hozzájárulhatnak a tudomány fejlődéséhez, és ezzel maguk is segíthetik a 
lombikeljárásokban részt vevők jövőbeni helyzetét. Itt tehát többen megint másfajta etikai keretekben értelmezték az embriót. Egyfelől olyan anyagként tekintettek rá, amely hasznos lehet a tudomány fejlődése szempontjából. Egyesek számára a tudomány fejlődése önmagában mint érték jelenik meg. Mások számára inkább az volt a meghatározó érv, hogy olyan fejlesztés valósuljon meg, ami segítheti a lombikeljárásokat a jövőben. Ebben az etikai keretben tehát az embrió hozzájárulhat a jövőbeni páciensek lehetőségeinek javulásához:

„Hogyha mi már nem használjuk fel, akkor inkább a tudomány, kísérletezzenek és próbáljanak, hátha valami okos dolgot, újabb kutatást, újabb jó dolgot találnak, kerülnek napvilágra, mert ez egy csoda, hogy ilyen létezik." (Beatrix)

„Egyáltalán nem semmisiteném meg, akkor vagy odaadnám, vagy kutatási célra. Semmiképpen sem a megsemmisités." (Laura)

Ugyanakkor volt olyan is, aki úgy érezte, ő nem tudná a megmaradt embrióját kutatási célra adományozni, épp amiatt, mert az emberi léthez kapcsolta őket. Szandra például az embriókat a kutatási célú felhasználás tekintetében „emberi lényként” emlegette, és ezért egyértelműen elutasította ezt a lehetőséget. Ugyanakkor, mivel nem voltak maradék embriói, és az interjú során hallott először erről a lehetőségről, korábban nem is szembesülhetett a dilemmát okozó nehézségekkel.

„Nem ajánlanám fel... ne játszadozzanak a kisbabáinkkal... tehát azok csak egy lények, emberi lények, és mert tényleg, mert itt van egy felnött ember... egy rokon... bárki szívesen venné, ha kísérleteznének vele." (Szandra)

Azt a lehetőséget, hogy a fagyasztott, felhasználásra nem kerülő embriók adományozásra kerüljenek más párok részére, az interjúalanyok elvetették. Érvelésükben elsősorban a tulajdonetikai és a rokonságetikai keretet használták. Az embrió egyrészt mint olyan különleges tulajdon jelent meg, amely tőlük származik és a sajátjuk, így nem szeretnék, ha más rendelkezne felette (tulajdonetikai keret). Felmerült, hogy gondot okozhatna annak meghatározása, pontosan kié a gyermek, kik tekinthetők a valós szülőknek. Azzal a vélekedéssel is találkoztunk, hogy az adományozók nem tudnának megküzdeni azzal, hogy a biológiai értelemben vett gyermeküket valaki más neveli:

„Hát nehéz kérdés, és egyik sem... Nincs jó választás, nyilván. Valahol az embernek... Tehát igazából a tudat... Hát jó... Hát hogyha tudok segíteni valamiben, de akkor is, ugye, az már egy... Egy... Kettő... Az ember... Kettőjük... Az emberből és a párjából ez egy élet... Tehát az maga. Ha akár eljátszik a tudattal az ember, hogy „Úristen, valaki más neveli a gyerekemet!”. Tehát ez etikailag mindig egy nehéz kérdés, és nehéz rá a választ adni." (Júlia) 
Az idézet is azt illusztrálja, hogy egy olyan embriót, amelyet más szülne meg, sokan rokonságetikai keretben értelmeznek, és a saját gyereküknek, rokonságukba tartozónak tekintenék.

\section{Következtetések}

Haimes és munkatársai (2008) külföldi páciens interjúalanyaihoz hasonlóan a hazai mintába került pácienseknél is megfigyelhető volt, hogy nem az etikai szakirodalom vitáinak „absztrakt” embriójában gondolkodtak. A hazai interjúalanyok többsége különböző módokon konstruálta meg az embriókat az idő, a helyük és a biológiai jellemzőik függvényében, illetve elsősorban annak megfelelően, hogy hogyan tudtak hozzájárulni a kezelési céljukhoz. A vizsgált interjúalanyok diskurzusaiban többféle etikai keret jelent meg az embriókkal kapcsolatos döntéseik során: ezek közül egyértelmúen a gyógykezelési etikai keret volt a domináns. Ez hasonló, mint amit Svendsen és Koch (2008) találtak egy klinikai dolgozók körében végzett dániai vizsgálat során, ugyanakkor teljesen más, mint amit Roberts (2007) figyelt meg a bemutatott ecuadori kutatása során. A magyarokkal szemben az ecuadori páciensek másra fókuszáltak, egyik részüknél az életetikai keret, másik részüknél a rokonságetikai keret volt meghatározó. Tehát korántsem automatikus és egyértelmű, hogy egy páciensnek a döntései során a saját kezelési érdekei, az anyagi és egészségügyi nehézségeinek minimalizálása-e az elsőrendű mérlegelendő szempont. Az ecuadori páciensek a rokonságetikai keretet alkalmazva elutasították a fagyasztást, ezzel nehezítve saját kezelésüket, hiszen így csak később, több költséggel és nagyobb egészségügyi kockázatokat vállalva vehettek részt újabb ciklusban. Illetve az életetikai keretben Ecuadorban a fagyasztásnál az került előtérbe, hogy addig is az embrió életben van: az embrió mint generikus érték jelentkezett.

A páciensinterjúk és az egy klinikán lefolytatott terepkutatás alapján vannak arra utaló jelek, hogy az embrióhierarchia jelen van már abban is, ahogyan a klinikai dolgozók kommunikálnak a páciensekkel. Úgy tűnik, a klinikai környezetben a nyelvi kódok, vizuális tartalmak sok szempontból alátámasztják és megerősítik az embrióhierarchiát. A klinikai dolgozók határozzák meg, hogy mi számít embriónak és mi nem, mi értékes és mi nem, ezt a szemléletet pedig a páciensek is átveszik. Azok az embriók, amelyek a klinikai kommunikáció középpontjában állnak, kerülnek a páciensek fókuszába is. A megfigyelés és az interjúk alapján úgy tünik, hogy előállhatnak olyan helyzetek, amikor ugyanazt a biológiai entitást ontológiailag másként prezentálják a páciensek felé. Az ontológiai váltásnak több okozója is lehet: egyfelól, hogy mennyiben járul hozzá majd feltehetően az adott embrió a páciens sikeres kezelési céljához, másrészt az embriónak a helye is meghatározó. A „maradék embriók” fogalmába gyakran a nem jó minősítésű, se beültetésre, se fagyasztásra nem kerülő embriók nem számítanak bele, így mintegy kikerülnek az embriónak minősítés köréből. Más helyzetekben azonban lehetnek olyan nem teljesen jó minősítésű embriók, amelyek beültetésre vagy 
fagyasztásra kerülnek, és ekkor teljes értékűen hangsúlyosak a diskurzusban, és egyértelmúen embriókként kezelik őket. Egyes esetekben, az embrió helyétől függően, a klinikán a páciensek felé történő kommunikációban ontológiai váltás történik. Ilyenkor a beültetés után vizuális és verbális eszközökkel is a kismama-baba párosítást sugallják, sok páciens pedig át is veszi ezt a szemléletet.

A meghatározó gyógykezelés-etikai keret mellett még több, más etikai keret is előfordult interjúinkban: tulajdonetikai keret, rokonságetikai keret, a tudomány fejlődéséhez kapcsolódó etikai keret, más páciensek segítéséhez kapcsolódó etikai keret, puha életetikai keret. Puha életetikai szempontok elsősorban a fagyasztott embriók további tárolása kapcsán merültek fel a beszámolókban - de úgy túnt, hogy sokaknál ekkor sem ezek voltak a döntéshozatal során a legfontosabb tényezők. A lombikeljárások egyik mellékterméke a maradék fagyasztott embriók nagy tömege, amelyek egy része vélhetően soha nem kerül majd felhasználásra. Az interjúk alapján úgy tűnik, sok páciens ezzel nincs tisztában, amikor az eljárás mellett dönt. A kezelések során a páciensek elsősorban az eljárás adott szakaszára koncentrálnak, illetve a hőn óhajtott terhességi célra, és nem gondolkodnak előre, mi lesz céljuk teljesülése után.

Az eredményeket nem lehet általánosítani - többek között a minta kis mérete és a lehetséges szelekciós hatás miatt sem, hiszen akik vállalták az interjúkat, eltérhetnek azoktól, akik nem vállalkoztak rá. További korlátját jelentik a kutatásnak, hogy csak női pácienseket kérdeztünk, csak egyetlen klinikán végeztünk megfigyelést, és ott is csak korlátozott módon, különben pedig retrospektív módon kérdeztük az interjúalanyokat, hogy emlékezzenek vissza az orvosi, klinikai kommunikációra. Óvatosan kell bánni az oksági kijelentésekkel is, hogy mennyiben befolyásolhatta a klinikai dolgozók szemlélete a páciensek percepcióit. Érvényesülhet egy olyan hatás is, hogy mivel mind a klinikai dolgozók, mind a páciensek ugyanabban a társadalomban élnek, ezért mindkét csoport egyszerúen a tágabb társadalom normáit tükrözi vissza. Ugyanakkor azt gondoljuk, hogy a potenciális társadalmi befolyáson túl amiatt lehetett az orvosi környezetnek kifejezett hatása, mert a tágabb környezet arra nem ad olyan részletes útmutatást, mint a klinika, hogy mi számít embriónak és mi nem. És ahogy láthattuk, a páciensek sok esetben a klinikaihoz hasonlóan konstruálták meg, hogy mit tekintenek embriónak és mit nem sorolnak ebbe a kategóriába.

Milyen gyakorlati implikációi vannak az eredményeknek? Míg Magyarországon az embriókat felhasználó kutatási lehetőségek sok esetben nagyon korlátozottak, az interjúinkból az látszik, hogy kutatási célra egyesek nyitottak lennének maradék embrióikat odaadományozni. Sőt lelkileg is jobb érzés lenne számukra, hiszen azt éreznék, hogy felajánlásukkal másokon segíthetnek és a kutatás fejlődéséhez járulhatnak hozzá.

Felmerül az is, hogy jó, ha a páciensek már az elején, teljes körűen informálva vannak a lombikeljárás melléktermékéről, a maradék fagyasztott embriókról. Így ennek a körülménynek a figyelembevételével tudják meghozni döntéseiket, hogy milyen módon vállalják a lombikeljárást. Amiatt is fontos a megfelelő és körültekintő informálás, hogy ne álljon elő olyan helyzet, hogy csak évekkel később szembesülnek 
a döntések következményeivel, ami akkor okoz rossz érzést számukra. Ugyanakkor, amennyiben nem olyan eljárást választanának, ahol sok maradék embrió képződhet (mert pl. nem kérnek hormonstimulációt, vagy csak annyi embriót hozatnak létre, amennyit beültetnek), drasztikusan rontanák a sikerességük esélyét. További potenciális érzelmi terhet jelenthetnének ezek az információk a párnak egy olyan időszakban, amely amúgy is tipikusan nehéz számukra. Az interjúkból ugyanakkor az is kirajzolódik, hogy az információ hiánya a kiszolgáltatottság érzését keltette a páciensekben. Egyes esetekben úgy élték meg, hogy a kezelés során nem értették a lépéseket - gyakran nem tudtak informált döntéseket hozni, ami frusztrációt okozott számukra egy emocionálisan amúgy is megterhelő élethelyzetben. Emiatt mégiscsak a minél teljesebb körű információ biztosítása válik fontossá. Brit meddőségi klinikákon végzett empirikus vizsgálatok is arra a következtetésre jutottak, hogy az etikailag komplex helyzetekben akkor tudnak a páciensek megalapozott döntéseket hozni, ha részletesek és teljes körűek az egészségügyi dolgozóktól kapott információik (Williams et al. 2002; Ehrich et al. 2007). A páciensek alapjoga, hogy az összes körülményt mérlegeljék autonóm döntéshozataluk során. Információ hiányában, annak szándékos vagy nem szándékolt elhallgatása vagy torzítása kapcsán a teljes informáltsághoz való páciensjog sérül (Kottow 2004).

\begin{abstract}
Ever since the birth of the first in vitro fertilization (IVF) baby in 1978, millions of infants worldwide have been conceived with the help of IVF. The study discusses what ethical frameworks we can see in the accounts of Hungarian IVF patients concerning their decisions about the embryo. The article also discusses what employees of the infertility clinics are communicating to patients and how they can influence their thinking. In the framework of the research, 20 semi-structured interviews were carried out with patients as well as observations at an infertility clinic. Nowadays, when many biopolitical decisions are passed on to patients, they have to make a number of different, often difficult decisions in the course of their IVF treatment. Based on the interviews, the article presents that the main ethical framework constructed by the interviewees is the therapeutic frame. An important feature of this frame is the embryo hierarchy: the majority of interviewees constructed the picture of the embryos in different ways, depending on time, place and biological characteristics, and primarily on how they could contribute to their treatment purpose. Based on the interviewees' accounts and our field research, we aim also to reconstruct how the clinical environment further strengthens the usage of the ethical frame. Strengthening is achieved, among other things, by the use of language codes, visual content, and the use of ontological manipulation (when biological entities are presented to patients in a substantially different nature according to what fate they proposed to have). In addition to the dominant ethical framework, we discuss the minority ethical frameworks in discourses.
\end{abstract}

Keywords: reproductive technology, technology and society, IVF, ethics

\title{
Köszönetnyilvánítás
}

A kutatást az OTKA/NKFIH K 108981 számú kutatása tette lehetővé. Vicsek Lilla munkáját a kutatás alatt az MTA Bolyai-ösztöndíja segítette. A szerzők köszönetet 
mondanak Takács Erzsébetnek a szakirodalomhoz kapcsolódó ötleteiért, Paksi Veronikának az interjúzásban besegítésért, az interjúalanyoknak, hogy ránk áldozták az idejüket, valamint a 2017-es éves OTKA kutatási jelentés anonim értékelőjének, aki az értékelés mellett jó tanácsokkal is segítette munkánkat.

\section{Irodalom}

Agar, N. (2007): Embryonic Potential and Stem Cells. Bioethics, 21(4): 198-207. https://doi.org/10.1111/j.1467-8519.2006.00533.x.

Akrich, M. (1992): The description of technical objects. In Bijker, W. E. - Law, J. (eds.): Studies in Sociotechnical Change. Cambridge MA: MIT Press, 205-224.

Akrich, M. - Latour, B. (1992): A Summary of a convenient vocabulary for the semiotics of humans an non-human assemblies. In Bijker W. E. - Law, J. (eds.): Studies in Sociotechnical Change. Cambridge MA: MIT Press, 259-264.

Anderson, B. (2005): Reproductive Health. Women and Men's Shared Responsibility. Sudbury: Jones and Bartlett Publishers.

Baruch, S. - Kaufman,D. J. - Hudson, K. L. (2008): Preimplantation genetic screening: A survey of in vitro fertilization clinics. Genetics in Medicine, 10(9): 685. doi:10.3390/jcm3010280.

Bauer, Zs. (2013): Bound together by fate and faith: A qualitative analysis of online discussions on assisted reproduction in Hungary. In Szekeres, V. (ed.): Proceedings of FIKUSZ '13 Symposium for Young Researchers. Budapest: Keleti Károly Faculty of Business and Management, Óbuda University, 109-121.

Bauer Zs. (2014a): „Laikus szakértő” páciensek, avagy a változó orvos-beteg viszony megélése és értékelése a meddőségkezelési eljárásban. Kultúra és Közösség, 45(3): 159-172. http://www.kulturaeskozosseg.hu/pdf/2014/3/13.pdf.

Bauer, Zs. (2014b): Systematic inequalities in medically assisted reproduction in Hungary - the patients' perspective. Proceedings STS Conference Graz 2014: Critical Issues in Science and Technology Studies, http://www.ifz.aau.at/ias/ IAS-STS/Publications/Proceedings-STS-Conference-Graz-2014 (letöltés 2014. 10. 15.).

Bauer Zs. (2017): „Laikus szakértő” páciensek, avagy a változó orvos-beteg viszony megélése és értékelése - elméletek és tapasztalatok - egy netnográfiai vizsgálat bemutatása. A Magyar Szociológiai Társaság éves konferenciája - MODERNITÁSOK, Egészség, betegség és társadalom a későmodernitásban - kvalitatív megközelítések szekció. Budapest, 2017. október 24-26.

Boivin, J. et al. (2007): International estimates of infertility prevalence and treatment-seeking: Potential need and demand for infertility medical care. $\mathrm{Hu}$ man Reproduction, 22(6): 1506-1512. doi: 10.1093/humrep/dem046.

Boltanski, L. (2013): The Foetal Condition: A Sociology of Engendering and Abortion. Cambridge: Polity Press. 
Braun,V.-Clarke, V.(2006):Usingthematicanalysisinpsychology. QualitativeResearch in Psychology, 3(2): 77-101. doi:http://dx.doi.org/10.1191/1478088706qp063oa.

De Lacey, S. (2007): Decisions for the fate of frozen embryos: Fresh insights into patients' thinking and their rationales for donating or discarding embryos. Human Reproduction, 22(6): 1751-1758. doi: https://doi.org/10.1093/humrep/ dem056.

Dorland's Medical Dictionary for Health Consumers (2007): Philadelphia: Saunders.

Ehrich, K. - Williams, C. - Farsides, B. - Sandall, J. - Scott, R. (2007): Choosing embryos: Ethical complexity and relational autonomy in staff accounts of PGD. Sociology of Health \& Illness, 29: 1091-1106. doi: 10.1111/j.14679566.2007.01021.x.

Ehrich, K. - Williams, C. - Farsides, B. (2010): Fresh or frozen? Classifying 'spare' embryos for donation to human embryonic stem cell research. Social Science \& Medicine, 71: 2204-2211. doi: 10.1016/j.socscimed.2010.09.045.

Ehrich, K. - Williams, C. - Farsides, B. - Scott, R. (2012): Embryo futures and stem cell research. Sociology of Health and Illness, 34(1): 114-129. doi: 10.1111/j.14679566.2011.01367.x.

Fannin, M. (2012): The burden of choosing wisely: Biopolitics at the beginning of life. Gender, Place \& Culture: A Journal of Feminist Geography, 20(3): 273-289. doi: https://doi.org/10.1080/0966369X.2012.694355.

Felt, U. - Fochler, M. - Winkler, P. (2010): Coming to terms with biomedical technologies in different techno-political cultures: A Comparative analysis of focus groups on organ transplantation and genetic testing in Austria, France and the Netherlands. Science, Technology, \& Human Values, 35(4): 525-553. doi: https://doi.org/10.1177/0162243909345839.

Frith, L. - Jacoby, A. - Gabbay, M. (2011): Ethical boundary work in the infertility clinic. Sociology of Health \& Illness, 33(4): 570-585. doi: 10.1111/j.14679566.2010.01308.x.

Franklin, S. (2013): Biological Relatives. Durham-London: Duke University Press.

Foucault, M. (1999): A szexualitás története I: A tudás akarása. Budapest: Atlantisz LEELL.

Gaskell, G. - Allansdottir, A. - Allum, N. - Corchero, C. - Fischler, C. - Hampel, J. (et al.) (2006): Europeans and biotechnology in 2005: Patterns and trends. Final Report on Eurobarometer 64.3. http://ec.europa.eu/research/biosociety/pdf/ eb_64_3_final_report_second_edition_july_06.pdf (letöltés 2010. 2. 24.).

Gottweis, H. (2002): Stem cell policies in the United States and in Germany. Policy Studies Journal, 30(4): 444-469.

Haimes, E. - Porz, R. - Scully, J. K. - Rehmann-Sutter. C. (2008): So what is an embryo? A comparative study of the views of those asked to donate embryos for hESC research in the UK and Switzerland. New Genetics and Society, 27(2): 113-126. do i:10.1080/14636778.2013.768424. 
Haimes, E. - Taylor, K. (2009): Fresh embryo donation for human embryonic stem cell (hESC) research. Human Reproduction, 24(9): 2142-2150. doi: 10.1093/ humrep/dep124.

Harvey, O. - Ehrich, K. (2011): Material agency in the laboratory and the clinic. Revista de Humanidades Médicas \& Estudios Sociales de la Ciencia y la Tecnología, 2(3), 1-17. http://www.ea-journal.com/art2.3/Material-agency-in-the-laboratoryand-the-clinic.pdf (letöltés 2013. 01. 18.).

Inhorn, M. C. (2003): Global infertility and the globalization of new reproductive technologies: Illustrations from Egypt. Social Science \& Medicine, 56: 1837-1851. DOI: 10.1016/s0277-9536(02)00208-3.

Jin, X. - Wang, G. X. - Liu, S. S. - Liu, M. - Zhang, J. - Shi, Y. F. (2013): Patients' attitudes towards the surplus frozen embryos in China. BioMed Research International, Article ID 934567, doi: http://dx.doi.org/10.1155/2013/934567.

Kalfoglou, A. L. - Scott, J. - Hudson, K. (2005): PGD patients' and providers' attitudes to the use and regulation of preimplantation genetic diagnosis. Reproductive Biomedicine online, 11(4): 486-496. doi: https://doi.org/10.1016/ S1472-6483(10)61145-5.

Kapitány B. (2012): A gyermekvállalási tervek beteljesületlenségének okai. Korfa, 12(2): 1-4.

Kirejczyk, M. (2008): On Women, egg cells and embryos gender in the regulatory debates on embryonic research in the Netherlands. European Journal of Womens Studies, 15(4): 377-391. doi: https://doi.org/10.1177/1350506808095295.

Kitzinger, J. ( 2007): Framing and frame analysis. In Devereux, E. (ed.): Media Studies: Key Issues and Debates. London, England: SAGE, 134-161.

Knoll, E. M. (2012): Reproducing Hungarians: reflections on fuzzy boundaries in reproductive border crossing. In Knecht, M. - Klotz, M. - Beck, S. (eds.): Reproductive Technologies as Global Form. Frankfurt am Main: Campus Verlag GmBH, 255-282.

Kottow, M. (2004): The battering of informed consent. Journal of Medical Ethics, 30(6): 565-569. doi: 10.1136/jme.2003.002949.

Latour, B. (1991): Technology is society made durable. In Law, J. (ed.): A Sociology of Monsters. Essays on Power, Technology and Domination. London: Routledge, 103131.

Latour, B. (1993): We Have Never Been Modern. New York: Harvester Wheatsheaf.

Málovics, É. - Veres, Z. - Lippai, L. - Nagy, Á. (2006): Competences and risk perception in medical services. Vth International Congress on Public and Non Profit Marketing. Konferencia CD.

Málovics É. - Vajda B. - Kuba P. (2009): Paternalizmus vagy közös döntés? Páciensek az orvos-beteg kommunikációról. In Hetesi E. - Lukovics M. (szerk.): A szolgáltatások világa. JATEPress Szeged, 250-264. 
Meister, U. et al. (2005): Knowledge and attitudes towards preimplantation genetic diagnosis in Germany. Human Reproduction, 20(1): 231-238. doi: https://doi. org/10.1093/humrep/deh548.

Memmi, D. (2012): Egy érzékeny terület igazgatása. Ésszerü magatartás és test általi felügyelet a születés és halál kapcsán. Replika, 79: 77-89.

Memmi, D. (2003): Governing through speech: The new state administration of bodies. Social Research, 70(2): 645-658.

Meyer, M. J. - Nelson, L. J. (2001). Respecting what we destroy: Reflections on human embryo research. Hastings Center Report, 31(1): 16-23. doi: https://doi. org/10.2307/3528728.

Meniru, G. I. (2004): Cambridge Guide to Infertility Management and Assisted Reproduction. Cambridge University Press.

Miettinen, A. - Szalma, I. (2014): Childlessness intentions and ideals in Europe. In Finnish Yearbook of Population Research, XLIX, 31-55.

Munné, S. et al. (2007): Maternal age, morphology, development and chromosome abnormalities in over 6000 cleavage-stage embryos. Reproductive Biomedicine online, 14(5): 628-634. doi: https://doi.org/10.1016/S1472-6483(10)61057-7.

Nakano-Okuno, M. (2006): Destroying vs. saving human lives: The utilitarian view on research using human embryos. https://www.academia.edu/1044438/ Destroying_vs_Saving_Human_Lives_The_Utilitarian_View_on_Research_ on_Human_Embryos_2006 (letöltés 2014.10.15.).

Navratyil Z. (2012): A varázsló eltöri pálcáját? A jogi szabályozás vonulata az asszisztált humán reprodukciótól a reproduktív klónozásig. Budapest: Gondolat Kiadó.

Neményi M. - Takács J. (2015): Örökbefogadás és diszkrimináció Magyarországon. Esély, 27(2): 32-61.

Neumann O. (2011): Köszönjük, hogy megszülettünk! Kaáli Intézet: 20 év - 20 000 gyermek. Budapest. https://kaali.hu/letoltesek/koszonjuk_hogy_ megszulettunk.pdf.

Perrotta ,M. (2013): The emerging meanings of reproductive cells among science, state, and religion. Tecnoscienza: Italian Journal of Science \& Technology Studies, 4(1): 7-22.

Prainsack, B. (2006): Negotiating life: The regulation of human cloning and embryonic stem cell research in Israel. Social Studies of Science, 36(2): 173-205.

Provost, V. - Pennings, G. - De Sutter, P. - Gerris, J. - Van de Velde, A. - Dhont, M. (2011): To continue or discontinue storage of cryopreserved embryos? Patients' decisions in view of their child wish. Human Reproduction, 2(1): 861-872. doi: https://doi.org/10.1093/humrep/deq392.

Reed, K. (2012): Gender and Genetics: Sociology of the Prenatal. London: Routledge.

Reis, P. (2008): How Brazilian and North American newspapers frame the stem cell research debate. Science Communication, 29(3): 316-334. doi: https://doi. org/10.1177/1075547007312394. 
Roberts, E. F. S. (2007): Extra embryos: The ethics of cryopreservation in Ecuador and elsewhere. American Ethnologist, 34(1): 181-199. doi:10.1525/ae.2007.34.1.181.

Sándor, J. (2009): Perfect copy? Law and ethics of reproductive medicine. In Budapest, CEU Center for Ethics and Law in Biomedicine, 1-175. http://www. librarything.com/work/9580433.

Sayer, A. (2004): Restoring the moral dimension: Acknowledging lay normativity, online paper, published by the Department of Sociology, Lancaster University, Lancaster LA14Yl, UK. http://www.comp.lancs.ac.uk/sociology/papers/sayerrestoring-moral-dimension.pdf (letöltés 2014. 10. 15.).

Shannon, T. A. - Wolter, A. B. (1990): Reflections on the moral status of the preembryo. Theological Studies, 51(4): 603-62.

Svendsen, M. N. - Koch, L. (2008): Unpacking the 'Spare Embryo': Facilitating stem cell research in a moral landscape. Social Studies of Science, 38(1): 93-110. doi: https://doi.org/10.1177/0306312707082502.

Szalma I. (2014): A gyermekvállalás társadalmi normái és a mesterséges megtermékenyítéssel kapcsolatos attitűdök vizsgálata Magyarországon és Európában. Replika, 35-57.

Szalma I. - Takács J. (2012): A gyermektelenséget meghatározó tényezők Magyarországon. Demográfia, 55(1): 44-68.

Szalma I. (2016): Az asszisztált reprodukciós eljárások elterjedtsége és elfogadottsága Magyarországon, európai kitekintésben. Magyar Tudomány. http://www. matud.iif.hu/2016/02/04.htm.

Szülészeti és Nőgyógyászati Szakmai Kollégium (2010): Az Egészségügyi Minisztérium szakmai protokollja meddőség ellátásról - asszisztált reprodukcióról - in vitro fertilizációról (1. módosított változat). Hivatalos Értesítő (A Magyar Közlöny Melléklete), 30. sz. 6467-6494.

Takács E. (2012): „Individuumszociológiák”. Modernitásmegközelítések a francia szociológiában. Replika, 79: 7-22.

Takács E. (2015a): Fogamzás és terhesség-megszakítás. Magzat-irodalom a kortárs francia szociológiában. SOCIO.HU, (1). https://socio.hu/uploads/files/2015_1/ takacs.pdf doi:10.18030/socio.hu.2015.1.105.

Takács E. (2015b): A születés esetlegességei. A prenatális diagnosztika szociológiai problematizálása. In Kisdi B. (szerk.): Létkérdések a születés körül. Társadalomtudományi vizsgálatok a szülés és születés témakörében. Budapest: L'Harmattan.

Thompson, C. (2005): Making Parents. Cambridge, Massachusetts - London, England: MIT Press.

Waldby, C. (2015): Banking time: Egg freezing and the negotiation of future fertility. Culture, Health, andSexuality, 17(4):470-482.doi:10.1080/13691058.2014.951881.

Warnock, M. (1985): A question of life: The Warnock report on human fertilisation and embryology.

Warren, M. A. (1997): Moral Status. Oxford: Oxford University Press. 
Warren, M. A. (1997): Moral Status: Obligations to persons and other living things. Oxford: Clarendon Press.

Wennberg, A. - Rodriguez Wallberg, K. - Milsom, I. - Brännström, M. (2016): Attitudes towards new assisted reproductive technologies in Sweden: A Survey in women 30-39 years of age. Acta Obstetricia et Gynecologica Scandinavica, 95(1): 38-44. doi: 10.1111/aogs.12781.

Williams, C. - Alderson, P. - Farsides, B. (2002): Drawing the line'in prenatal screening and testing: Health practitioners' discussions. Health, Risk \& Society, 4(1):61-75. doi: https://doi.org/10.1080/13698570210294.

Závecz Research (2017): Ritka nagy egyetértés van a lombikprogramról. https:// index.hu/belfold/2017/10/25/lombikprogram_felmeres_zavecz/.

Zegers-Hochchild, F. (et al. )(2009): International Committee for Monitoring Assisted Reproductive Technology (ICMART) and the World Health Organization (WHO) revised glossary of ART terminology, 2009. Fertil Steril, 92(5), 1520-1524. doi: 10.1093/humrep/dew082. 